\title{
Article \\ Degradation of Selected Antidepressants Sertraline and Citalopram in Ultrapure Water and Surface Water Using Gamma Radiation
}

\author{
Anna Bojanowska-Czajka *, Marta Pyszynska, Agnieszka Majkowska-Pilip (D) and Kamil Wawrowicz (D)
}

Institute of Nuclear Chemistry and Technology, 03-195 Warsaw, Poland; m.pyszynska@ichtj.waw.pl (M.P.) a.majkowska@ichtj.waw.pl (A.M.-P.); k.wawrowicz@ichtj.waw.pl (K.W.)

* Correspondence: a.bojanowska@ichtj.waw.pl

\begin{abstract}
Gamma radiation was applied to degradation selected antidepressants in ultrapure water and surface water. Additionally, the influence of typical radical scavengers like carbonate, nitrate and humic acid was determined. The cytotoxicity towards liver cells HepG2 and colon cells Caco2 were measured during the radiation process. It was found that radiation technology, specifically ionizing radiation, can achieve satisfactory degradation efficiency with both SER and CIT. It was shown that the process of decomposition of the tested antidepressants with the highest efficiency occurs in the reaction with the hydroxyl radical.
\end{abstract}

Keywords: antidepressants; sertraline; citalopram; gamma radiation; cytotoxicity monitoring; water and wastewater

check for

updates

Citation: Bojanowska-Czajka, A.; Pyszynska, M.; Majkowska-Pilip, A.; Wawrowicz, K. Degradation of Selected Antidepressants Sertraline and Citalopram in Ultrapure Water and Surface Water Using Gamma Radiation. Processes 2022, 10, 63. https://doi.org/10.3390/pr10010063

Academic Editor: George Z. Kyzas

Received: 1 December 2021

Accepted: 23 December 2021

Published: 28 December 2021

Publisher's Note: MDPI stays neutral with regard to jurisdictional claims in published maps and institutional affiliations.

Copyright: (c) 2021 by the authors. Licensee MDPI, Basel, Switzerland. This article is an open access article distributed under the terms and conditions of the Creative Commons Attribution (CC BY) license (https:// creativecommons.org/licenses/by/ $4.0 /)$.

\section{Introduction}

Recently, more and more attention has been paid to the so-called micropollutants occurring in water and sewage, and it is mainly about increasing awareness of the negative impact of these compounds and their degradation products on the natural environment and, consequently, on animal and human health. Micropollutants are compounds that occur at relatively low levels in water, sewage, soil and sewage sludge. They can reach the environment by being transported and distributed via different routes. The physicochemical properties of these compounds (e.g., water solubility, vapor pressure and polarity) determine their behavior in the environment. The group of micropollutants include pesticides, endocrine disruptors, personal care products, detergents, microplastics and of course pharmaceuticals. Pharmaceuticals as well as their residues constitute a special group of pollutants, mainly because they are excreted outside the body in approx. $95 \%$ of their unchanged form, from where they end up in sewage treatment plants [1]. A group of pharmaceuticals whose increase in consumption has particularly increased in recent years are drugs used to treat depressive disorders, which is due especially to the increasing lifestyle in highly developed countries [2] and, for example, the need for isolation caused by the COVID-19 pandemic [3]. It is estimated that globally about 350 million people suffer from depressive disorders, which is an essential cause of handicaps and suicides [4]. Among the antidepressants (ADs) of the so-called new generation due to this mechanism of action, can be separated into the following groups of compounds: selective serotonin reuptake inhibitors (SSRI), serotonin-norepinephrine reuptake inhibitors (SNRI), serotonin modulators and stimulators (SMS), serotonin antagonists and reuptake inhibitors (SARI), norepinephrine reuptake inhibitors (NRI), norepinephrine-dopamine reuptake inhibitors (NDRI), tricyclic antidepressants (TCA), tetracycline antidepressants (TeCA), monoamine oxidase inhibitors (MAOI) and receptor antagonists (NMDA), interacting directly with neuroreceptors [5].

For this study two drugs from SSRI group were selected, which were among the most commonly prescribed antidepressants, sertraline SER and citalopram CIT [6,7] Scheme 1. 


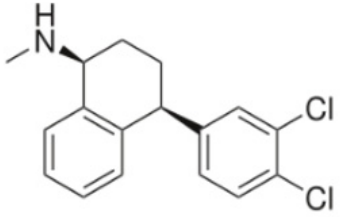

Sertraline $\mathrm{C}_{17} \mathrm{H}_{17} \mathrm{Cl}_{2} \mathrm{~N}$

Molar mass $306.23 \mathrm{~g} / \mathrm{mol}$

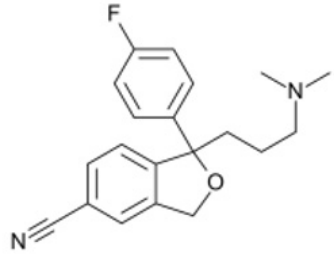

Citalopram $\mathrm{C}_{20} \mathrm{H}_{21} \mathrm{FN}_{2} \mathrm{O}$

Molar mass $324.39 \mathrm{~g} / \mathrm{mol}$

Scheme 1. SER and CIT chemical structure.

The widespread, constantly growing consumption of these type of drugs increases the level of their concentrations, as well as their degradation products in the natural environment. The occurrence of sertraline and citalopram in both wastewater and surface water has been reported several times in the range of ng/L [8-12]. The maximum concentration of citalopram $8000 \mathrm{ng} / \mathrm{L}$ was found in surface water near pharmaceutical production in India [13], for sertraline the highest concentration $1 \mu \mathrm{g} / \mathrm{L}$ were reported for two WWTP effluents discharging into the east-branch of the Niagara River located in the USA [14]. It was also shown that citalopram and sertraline adsorb into sediment where they remain stable [8]. Other studies have found sertraline in fish samples taken from the wild in the USA, which is indicative of potential bioaccumulation, while it was not reported whether and how, the sertraline level of $4.3 \mathrm{ng} / \mathrm{g}$ detected in the brain affects the nervous system of fish [15]. The determination of drug residues in environmental matrices at very low levels is possible due to the continuous development of new, more sensitive and accurate analytical methods and techniques [16-18]. Numerous methods for the analytical determination of biological and environmental matrices involve sample clean-up and preconcentration steps, using primarily solid-phase extraction (SPE) with different sorbents, and then reversed phase HPLC with tandem mass spectrometry detection (LC/MS/MS) [18-22]. The regular identification of pharmaceuticals, including sertraline and citalopram in the environment in surface water or wastewater, indicates that conventional wastewater treatment plants based mainly on activated sludge action are not effective against this type of pollution $[23,24]$. Pharmaceuticals are anthropogenic pollutants with very complex chemical structures that are very often resistant to biodegradation [25]. It was shown that at $25^{\circ} \mathrm{C}$, the total decomposition of sertraline in a simulated wastewater treatment plant, was about $27 \%$ after $72 \mathrm{~h}$ and for initial concentration of $2 \mu \mathrm{g} / \mathrm{L}$, for citalopram under the same conditions it was $13.5 \%$ [22]. It is interesting to note that for sertraline the contribution of biodegradation, adsorption and hydrolysis was 17.3; 9.8 and 1.6\%, respectively, and for citalopram these values were 13.5; 6.7 and 1.9\%, respectively. Pharmaceuticals used by humans, among them ADs, are always found in the environment in a mixture of other more or less toxic contaminants, so always the effects that pharmaceutical residues can cause in the environment should be looked at through the context of all the components present in water or wastewater [26]. The risks associated with chronic single drug exposure are considerable; however, multi-component mixtures of active substances and related residues can activate many biological molecules in the body. A mixture of pharmaceuticals in the body may cause effects: synergistic (the effect of the mixture is greater than the sum of its components), additive (the effect of the mixture is the sum of the effects of individual pharmaceuticals) or antagonistic (the mixture has an effect lower than the effect of a single compound, e.g., enzyme induction). For this reason, multi-component mixtures, e.g., wastewater or surface water, must be tested for overall environmental/living organism effects, and the effects may vary even for small changes in mixture composition [27]. One recent study indicates that the presence of microplastics increased sertraline's immunotoxicity to marine organisms. Plastic nanoparticles alone or in combination with other micropollutants, in this case sertraline, may have a more toxic effect on marine organisms than large plastic macroparticles [28]. Increasing public awareness of the threat posed by 
this type of micropollution forces the institutions responsible for monitoring water quality to introduce new, more detailed and restrictive legal regulations on the quality of water resources. One such document is The EU Water Framework Directive WFD 2000/60/EC, which obliges all member states to ensure the well-being of national waters. All these activities consequently lead to the search for new more efficient and effective methods of monitoring and removing micropollutants, including pharmaceuticals, from water and wastewater. One of the intensively developed directions in recent years are the so-called Advanced Oxidation/Reduction Processes, whose common feature is the generation of reactive individuals of oxidizing and reducing character directly in the in situ reaction environment. Radiation technologies based on gamma radiation and an electron beam from the accelerator are also classified as AOP processes. To the best of our knowledge, no studies have yet been carried out on the application of radiation technologies for the degradation of sertraline and citalopram residues in water and wastewater. Decomposition of these compounds were examined by other advanced oxidation processes (See Table 1). For instance, degradation of citalopram during water treatment was investigated using ozone, $\mathrm{ClO}_{2}$, UV radiation and the Fenton process, with optimal results obtained for photolytic decomposition [29]. Decomposition of sertraline utilized a photocatalytic process with $\mathrm{TiO}_{2}$ [30], by solar photo-Fenton oxidation [31], and also by reacting with zero-valent iron in the presence of $\mathrm{H}_{2} \mathrm{O}_{2}$ [32]. This paper presents results obtained for the application of gamma radiation for degradation in real solutions of selected antidepressants sertraline and citalopram. An attempt has also been made to identify the degradation products and to evaluate the cytotoxicity.

Table 1. Degradation sertraline and citalopram in different AOP processes.

\begin{tabular}{|c|c|c|c|c|c|c|}
\hline Compound & Type of AOP/R & $\begin{array}{c}\text { Conditions of } \\
\text { Treatment }\end{array}$ & $\begin{array}{l}\text { Treated } \\
\text { Media }\end{array}$ & $\begin{array}{c}\text { Initial } \\
\text { Concentration }\end{array}$ & $\begin{array}{c}\text { Yield of } \\
\text { Decomposition }\end{array}$ & Ref. \\
\hline Citalopram & Photochemical & $\begin{array}{c}254 \mathrm{~nm} \\
254 \mathrm{~nm}+0.42 \mathrm{mmol} / \mathrm{L} \\
\mathrm{H}_{2} \mathrm{O}_{2}\end{array}$ & $\begin{array}{l}\text { Ultrapure Water } \\
\text { 1. Ultrapure water } \\
\text { 2. Drinking tap Water } \\
\text { 3. Surface Water }\end{array}$ & $\begin{array}{l}25 \mu \mathrm{g} \mathrm{L}^{-1} \\
25 \mu \mathrm{g} \mathrm{L}^{-1}\end{array}$ & $\begin{array}{l}60 \% \text { at } 30 \mathrm{~min} \\
100 \% \text { at } 30 \mathrm{~min} \\
90 \% \text { at } 30 \mathrm{~min} \\
90 \% \text { at } 60 \mathrm{~min}\end{array}$ & [33] \\
\hline Citalopram & $\begin{array}{l}\text { Chlorination } \\
\text { Photochemical }\end{array}$ & $\begin{array}{l}\text { Sodium hypochlorite } \\
\text { solution } \\
5 \mathrm{mg} / \mathrm{L} \text { free chlorine } \\
254 \mathrm{~nm}\end{array}$ & $\begin{array}{l}\text { Raw water } \\
\text { Raw water }\end{array}$ & $\begin{array}{l}0.5 \mathrm{mg} \mathrm{L}^{-1} \\
0.5 \mathrm{mg} \mathrm{L}^{-1}\end{array}$ & $\begin{array}{c}100 \% \text { at } 30 \mathrm{~min} \\
100 \% \text { at } 175 \mathrm{~min}\end{array}$ & [34] \\
\hline $\begin{array}{l}\text { Citalopram } \\
\text { Sertraline } \\
\text { Citalopram } \\
\text { Sertraline }\end{array}$ & Ozonation & $\begin{array}{l}5 \mathrm{mg} \mathrm{L}^{-1} \text { ozone } \\
9 \mathrm{mg} \mathrm{L}^{-1} \text { ozone }\end{array}$ & $\begin{array}{l}\text { Primary-treated effluent } \\
\text { Primary-treated effluent }\end{array}$ & $\begin{array}{l}186 \mathrm{ng} \mathrm{L}^{-1} \\
14 \mathrm{ng} \mathrm{L}^{-1} \\
148 \mathrm{ng} \mathrm{L}^{-1} \\
9.4 \mathrm{ng} \mathrm{L}^{-1}\end{array}$ & $\begin{array}{c}34 \% \\
100 \% \\
62 \% \\
100 \%\end{array}$ & [35] \\
\hline Sertraline & Photochemical & $\begin{array}{c}\text { pH } 5.5 \\
\text { pH 7.0 } \\
\text { pH } 12.0 \\
\text { pH } 5.5 \\
\text { pH 7.0 } \\
\text { pH } 12.0\end{array}$ & $\begin{array}{l}\text { Surface water } \\
\text { Surface water }\end{array}$ & $\begin{array}{l}10 \mu \mathrm{g} \mathrm{L}^{-1} \\
1 \mathrm{mg} \mathrm{L}^{-1}\end{array}$ & $\begin{array}{c}\mathrm{T}_{1 / 2}>60 \mathrm{~h} \\
\mathrm{~T}_{1 / 2}=11.6 \mathrm{~h} \\
\mathrm{~T}_{1 / 2}=5.78 \mathrm{~h} \\
\mathrm{~T}_{1 / 2}>60 \mathrm{~h} \\
\mathrm{~T}_{1 / 2}=28.9 \mathrm{~h} \\
\mathrm{~T}_{1 / 2}=11.6 \mathrm{~h}\end{array}$ & [36] \\
\hline Sertraline & $\begin{array}{l}\text { Photo-Fenton } \\
\text { oxidation }\end{array}$ & $\begin{array}{l}\text { Dark Fenton }+40 \% \text { of the } \\
\text { stoichiometric } \mathrm{H}_{2} \mathrm{O}_{2} \text { dose } \\
\text { and } 5 \mathrm{mg} \mathrm{L}^{-1} \mathrm{Fe}^{2+}\end{array}$ & Distilled water & $50 \mathrm{mg} \mathrm{L}^{-1}$ & TOC $90 \%$ reduction & [31] \\
\hline Ciatlopram & $\begin{array}{l}\text { Ozonation } \\
\text { UV radiation }\end{array}$ & $\begin{array}{l}400 \mathrm{mg} \mathrm{L}^{-1} \\
\text { Polychromatic light (an } \\
\text { enhanced emission between } \\
250 \text { and } 190 \mathrm{~nm} \text { ) }\end{array}$ & $\begin{array}{l}\text { Distilled water } \mathrm{pH} 7 \\
\text { Distilled water } \\
\text { pH } 7\end{array}$ & $\begin{array}{l}100 \mu \mathrm{g} \mathrm{L}^{-1} \\
100 \mu \mathrm{g} \mathrm{L}^{-1}\end{array}$ & $\begin{array}{c}85 \% \text { at } 20 \min (\max ) \\
100 \% \text { at } 15 \min \end{array}$ & [29] \\
\hline Citalopram & $\begin{array}{l}\text { Natural sunlight } \\
\text { Simulated solar } \\
\text { irradiation } \\
\text { Photocatalytic }\end{array}$ & $\begin{array}{c}\text { Solar irradiation (outdor) } \\
\text { Xenon lamp } 1500 \mathrm{~W} \\
\text { 295-400 } \mathrm{nm} \\
\mathrm{TiO}_{2} \\
400 \mathrm{mg} \mathrm{L}^{-1}\end{array}$ & $\begin{array}{c}\text { Milli Q } \\
\text { Lake water } \\
\text { WWTP } \\
\text { Milli Q } \\
\text { Lake water } \\
\text { WWTP } \\
\text { Milli Q }\end{array}$ & $\begin{array}{l}10 \mathrm{mg} \mathrm{L}^{-1} \\
10 \mathrm{mg} \mathrm{L}^{-1} \\
10 \mathrm{mg} \mathrm{L}^{-1} \\
10 \mathrm{mg} \mathrm{L}^{-1} \\
10 \mathrm{mg} \mathrm{L}^{-1} \\
10 \mathrm{mg} \mathrm{L}^{-1} \\
20 \mathrm{mg} \mathrm{L}^{-1}\end{array}$ & $\begin{array}{c}\mathrm{T}_{1 / 2}=3456.74 \mathrm{~h} \\
\mathrm{~T}_{1 / 2}=693.15 \mathrm{~h} \\
\mathrm{~T}_{1 / 2}=462.10 \mathrm{~h} \\
\mathrm{~T}_{1 / 2}=61.89 \mathrm{~h} \\
\mathrm{~T}_{1 / 2}=25.77 \mathrm{~h} \\
\mathrm{~T}_{1 / 2}=23.42 \mathrm{~h} \\
100 \% \text { at } 30 \mathrm{~min} \\
90 \% \text { TOC reduction } \\
\text { at } 5 \mathrm{~h}\end{array}$ & [37] \\
\hline Sertraline & $\begin{array}{c}\text { Simulated } \\
\text { solar irradiation }\end{array}$ & $\begin{array}{c}\text { Xenon arc lamp } 1500 \mathrm{~W} \\
300-800 \mathrm{~nm}\end{array}$ & Milli Q & $1 \mathrm{mg} \mathrm{L}^{-1}$ & $60 \%$ at $65 \mathrm{~min}$ & [38] \\
\hline
\end{tabular}




\section{Materials and Methods}

\subsection{Materials}

All chemicals' reagents used in this study were of high purity analytical grade: sertraline SER hydrochloride and citalopram hydrobromide CIT were supplied by Sigma-Aldrich and formic acid by Baker. All the solution were prepared using ultrapure water obtained from Milli-Q equipment (Millipore). In the cytotoxicity measurements, the cell lines were human hepatic cell line HepG2 and colon cell line Caco2 purchased from the American Type Culture Collection (ATCC, Rockville, MD, USA) and maintained according to the ATCC protocol. Briefly speaking, HepGH2 and Caco2 cells were cultured in an EMEM medium supplemented with 10\% fetal calf serum (Gibco), and HepG2 cells were incubated in $5 \% \mathrm{CO}_{2}$ atmosphere.

\subsection{Irradiation Procedure}

Irradiation studies were performed using ${ }^{60}$ Co source Gamma Chamber 5000 with an absorbed dose rate of $2.15 \mathrm{kGy} \mathrm{h}^{-\mathrm{h}}$. The irradiation chamber was equipped with a rotation system to ensure employing a uniform absorbed dose throughout the irradiation volume. The $5 \mathrm{~mL}$ ultrapure (Milli-Q) water and river water samples used for the irradiation were spiked with $1 \mathrm{mg} \mathrm{L}^{-1}$ and $10 \mathrm{mg} \mathrm{L}^{-1}$ for SER and $1 \mathrm{mg} \mathrm{L}^{-1} \mathrm{CIT}$, respectively, prior to the irradiation with the absorbed dose magnitude up to $500 \mathrm{~Gy}$. Closed conical glass flasks containing $10 \mathrm{~mL}$ were used for the irradiation samples at an initial concentration of $10 \mathrm{mg} \mathrm{L}^{-1}$ and $1 \mathrm{mg} \mathrm{L}^{-1}$, which were saturated before the irradiation with Ar or $\mathrm{N}_{2} \mathrm{O}$. The dosimetry was carried out with Fricke dosimeter and the experiments were performed at room temperature $\left(25 \pm 2{ }^{\circ} \mathrm{C}\right)$. In each case, irradiation was performed in triplicate. During irradiation at the gamma source, rotation of the cage containing the sample was applied, which averaged the absorbed dose. Based on the results, the measurement uncertainty was estimated to be $6 \%$.

\subsection{Analytical Methods}

The SER and CIT concentration monitoring and identification of degradation products were carried out with the use of LC/MS analysis, employing the HPLC chromatograph Agilent Infinity 1290 with a mass spectrometer Agilent 6530 Q-TOF using electrospray ionization (ESI). The mass spectra in the m/zrange between 100 and 1700 were recorded for each analyzed sample. The chromatographic separation was carried out using an Agilent Bonus RP column $(2.1 \times 50 \mathrm{~mm}, 1.8 \mu \mathrm{m})$. The HPLC separations were carried out using gradient elution with the following eluents $\mathrm{A}$ : $0.1 \%$ formic acid in water and $\mathrm{B}: 0.1 \%$ formic acid in $\mathrm{ACN}$, and the flow rate was $0.4 \mathrm{~mL} / \mathrm{min}$. The gradient program was as follows: 0-1.5 min: A-95\% and B-5\%, 7.7-10 min concentration; B increased from 5 to $60 \%, 12-13 \mathrm{~min}$ concentration B 95\%, 15 min: A concentration 95\%. The MS conditions were as follows: dual AJS ESI with positive ion polarity, the flow-rate of drying gas was $8 \mathrm{~L} \mathrm{~min}^{-1}$, sheath gas temperature of $200{ }^{\circ} \mathrm{C}$, the flow-rate of sheath gas $11 \mathrm{~L} \mathrm{~min}^{-1}$, fragmentor voltage of $110 \mathrm{~V}$, and skimmer voltage of $65 \mathrm{~V}$. Determination of ionic products of degradation of SER and CIT (chloride, fluoride, nitrate and nitrite) were carried out using $4.5 \mathrm{~mm}$ of $\mathrm{Na}_{2} \mathrm{CO}_{3}$ and $0.8 \mathrm{~mm}$ of $\mathrm{NaHCO}_{3}$ as eluents, with sample volume $50 \mu \mathrm{L}$ and flow-rate $1 \mathrm{~mL} / \mathrm{min}$, and use of conductivity detection.

\subsection{Cytotoxicity Monitoring}

The impact of SER and CIT prior to the $\gamma$-irradiation and after the irradiation in aerated aqueous solutions of 10 and $1.0 \mathrm{mg} \mathrm{L}^{-1}$ concentrations at the metabolic activity of HepG2 and Caco2 cells was measured by MTS tetrazolium assay. Briefly speaking, both cell lines were seeded in 96-well microplates ((TPP Techno Plastic Products AG, Trasadingen, Switzerland) at the density of $1 \times 10^{4}$ cells per well in $100 \mu \mathrm{L}$ of a culture medium. At least three independent experiments in six replicate wells were conducted. Twenty-four hours after cell seeding, the cells were treated for 24,48 and $72 \mathrm{~h}$ with an increasing concentration of the SER and CIT, respectively. After the above-mentioned treatment, $20 \mu \mathrm{L}$ CellTiter 
96 Aqueous One Solution Cell Proliferation Assay (Promega, Madison, WI, USA) was added to each well and the cells were incubated for $3 \mathrm{~h}$. The assessment of metabolic activity was described as relative colorimetric changes measured at $490 \mathrm{~nm}$ in a plate reader spectrophotometer called Infinite M200 (Tecan, Grödig, Austria).

\section{Results}

\subsection{Radiolytic Degradation}

Radiation technologies used in environmental protection, and in the removal of pollutants from water and wastewater, are based on the in situ generation of reactive individuals capable of oxidizing or reducing pollutants. These individuals are produced in the water radiolysis process both under the influence of gamma radiation and electron beam, in accordance with Equation (1).

$$
\mathrm{H}_{2} \mathrm{O} \rightarrow \bullet{ }^{\bullet} \mathrm{OH}(2.7)+e_{a q}^{-}(2.6)+\mathrm{H}^{\bullet}(0.55)+\mathrm{H}_{2}(0.45)+\mathrm{H}_{2} \mathrm{O}_{2}(0.71)+\mathrm{H}_{3} \mathrm{O}^{+}
$$

The efficiency of the irradiation process is evaluated by calculating the chemical yield of the radiation ( $G$-value, $\mu \mathrm{M} \mathrm{J}-1$ ), which determines the number of individuals of a given type formed or decomposed because of $100 \mathrm{eV}$ absorption and is represented by Equation (2).

$$
G=\frac{6.023 \times 10^{23} \mathrm{C}}{D \times 6.24 \times 10^{16}}
$$

As compared to other AOPs, a unique feature of the process is simultaneous generation of both strongly oxidizing $\left({ }^{\bullet} \mathrm{OH}\right)$ and strongly reducing $\left(e_{\mathrm{aq}}{ }^{-}\right.$and $\left.{ }^{\bullet} \mathrm{H}\right)$ various structure and different redox potentials species which can react with organic pollutants of various structures and different redox potentials. Radiolytic degradation of both sertraline and citalopram was carried out in aqueous solutions at concentrations of $1 \mathrm{mg} / \mathrm{L}$ with radiation doses ranging from 0 to $500 \mathrm{~Gy}$. It appears that both pharmaceuticals can be effectively removed from aerated solutions at relatively low doses as shown in (Figure 1B,C). At an initial concentration of $1 \mathrm{mg} / \mathrm{L}$, almost complete degradation of sertraline and citalopram was achieved after a dose of $100 \mathrm{~Gy}$. Furthermore, sertraline was almost completely degraded after a dose of $200 \mathrm{~Gy}$ when the initial concentration was increased 10-fold to $10 \mathrm{mg} / \mathrm{L}$ (Figure 1A). To decompose the same amount of CIT, the dose $400 \mathrm{~Gy}$ is needed. For the applied gamma radiation source with a dose rate of $2.15 \mathrm{kGy}$. it is less than $11 \mathrm{~min}$. This suggests that ionizing radiation is an effective method of degrading sertraline and citalopram compared to traditional biochemical or other AOP methods. Three different redox systems were performed to confirm which active radical of all the major radicals generated during water radiolysis played a leading role in the degradation of sertraline and citalopram: The solutions were saturated with $\mathrm{N}_{2} \mathrm{O}$, aerated and saturated with $\mathrm{Ar}$ (to remove air before irradiation) and irradiated in the presence of tert-butanol addition. The commonly used way of ensuring the predominance of ${ }^{\bullet} \mathrm{OH}$ radicals in irradiated solutions is their saturation with $\mathrm{N}_{2} \mathrm{O}$, which is a result of the following reaction (2).

$$
e_{a q}^{-}+\mathrm{N}_{2} \mathrm{O}+\mathrm{H}_{2} \mathrm{O} \rightarrow \mathrm{N}_{2}+\mathrm{OH}^{-}+\bullet \mathrm{OH}^{\circ}=9.1 \times 10^{9} \mathrm{M}^{-1} \mathrm{~s}^{-1}
$$

This causes the conversion of $e_{\mathrm{aq}}{ }^{-}$into additional amount of ${ }^{\bullet} \mathrm{OH}$ radicals. On the other hand, the predominance of $e_{\mathrm{aq}}{ }^{-}$in irradiated solutions is ensured by their deaeration and addition of a sufficient amount of tert-butanol ( $0.5 \mathrm{~m}$ in this case). This results in the scavenging of ${ }^{\bullet} \mathrm{OH}$ radicals according to this reaction (3):

$$
\bullet \mathrm{OH}+\left(\mathrm{CH}_{3}\right)_{3} \mathrm{COH} \rightarrow \mathrm{H}_{2} \mathrm{O}+{ }^{\bullet} \mathrm{CH}_{2}\left(\mathrm{CH}_{3}\right)_{2} \mathrm{COH} k=6 \times 10^{8} \mathrm{M}^{-1} \mathrm{~s}^{-1}
$$

When the irradiation is carried out in the aerated solutions, there are two predominantly reactive radicals, namely ${ }^{\bullet} \mathrm{OH}$ and superoxide radical anion $\mathrm{O}_{2}{ }^{\bullet-}$, which are 
generated as a result of the scavenging of the hydrated electrons (4) and $\bullet H$ radicals by oxygen (5):

$$
\begin{gathered}
e_{a q}^{-}+\mathrm{O}_{2} \rightarrow \mathrm{O}_{2}^{\bullet-} \\
{ }^{\bullet} \mathrm{H}+\mathrm{O}_{2} \rightarrow \mathrm{HO}_{2}^{\bullet} \leftrightarrow \mathrm{H}^{+}+\mathrm{O}_{2}^{\bullet-}
\end{gathered}
$$

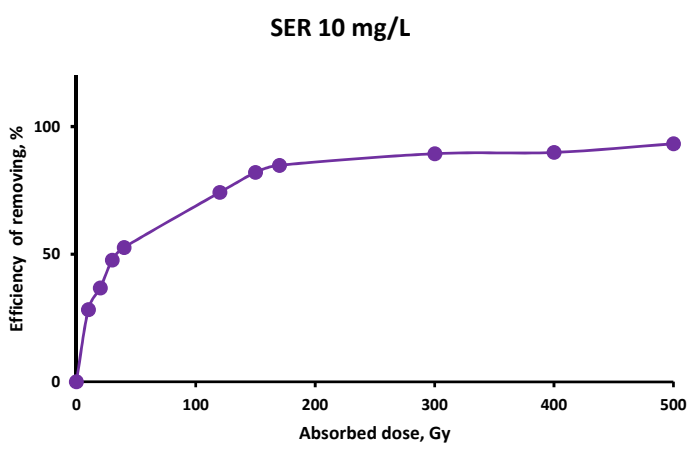

(A)

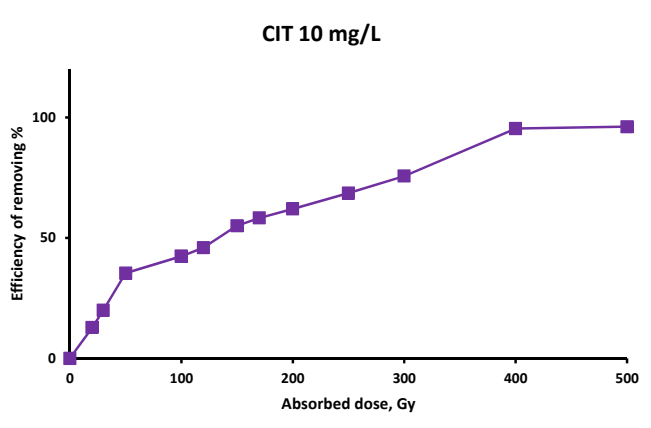

(C)

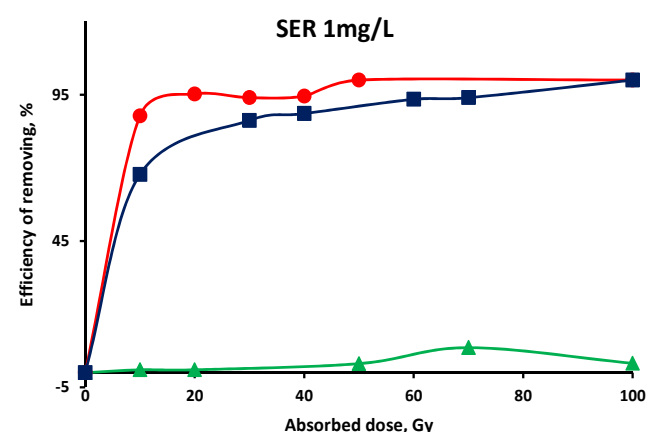

(B)

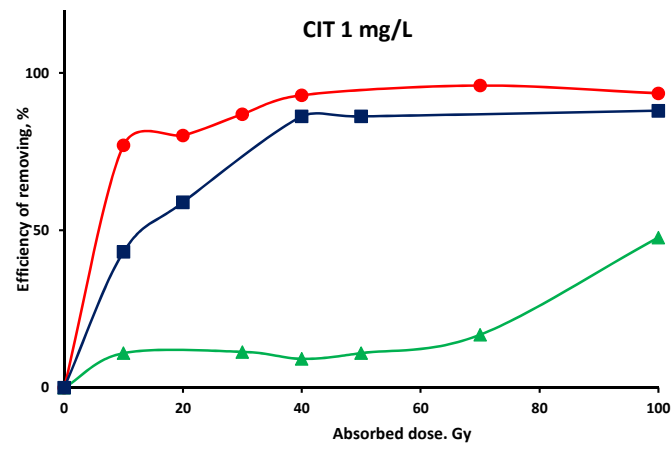

(D)

Figure 1. Efficiency of removing ADs from aqueous solution using gamma radiation under different conditions: (A) $10 \mathrm{mg} / \mathrm{L}$ sertraline, (B) $1 \mathrm{mg} / \mathrm{L}$ sertraline and (C) $10 \mathrm{~m} / \mathrm{L}$ citalopram, (D) $1 \mathrm{mg} / \mathrm{L}$ citalopram. Conditions of irradiation: $(\boldsymbol{\Delta})$ solution saturated with argon in the presence of $\mathrm{t}$-butanol at $\mathrm{pH}$ 7-solvated electrons predominate, $(\bullet)$ solution saturated with $\mathrm{N}_{2} \mathrm{O} \bullet \mathrm{OH}$ radicals predominate, $(\bullet, \bullet)$ aerated neutral solution with reactive species $\bullet \mathrm{OH}$, and $\mathrm{O}_{2}{ }^{\bullet} / \mathrm{HO}_{2} \bullet$.

Figure $1 B, D$, indicate that the highest degradation efficiency of both $1 \mathrm{mg} / \mathrm{L} \mathrm{SER}$ and $1 \mathrm{mg} / \mathrm{L}$ CIT was obtained in the system dominated by hydroxyl radicals, followed by the aerated system, whereas the degradation efficiency was lowest in the system containing tert-butanol under $e_{\mathrm{aq}}{ }^{-}$dominant conditions. From this it can be concluded that the degradation reaction under ionizing radiation of both sertraline and citalopram is indeed a strong oxidative reaction. The obtained data on the formation of the main ionic degradation products also indicate that the highest efficiency of the degradation process of SER and CIT was obtained under oxidative conditions Figures 2 and 3. For $1 \mathrm{mg} / \mathrm{L} \mathrm{SER}$, after absorbing a dose of $20 \mathrm{~Gy}$, more than $90 \%$ degradation efficiency was observed and at the same time $80 \% \mathrm{Cl}$ removal efficiency was achieved from the molecule. Similarly, for $1 \mathrm{mg} / \mathrm{L}$ CIT, $90 \%$ degradation efficiency at a dose of 100 Gy suits to almost $90 \%$ defluorization. The obtained results clearly indicate the potential application of radiation technologies for the removal of SER and CIT residues. It is important to add that delivery of necessary doses of ionizing radiation to the system takes place in a very short time. For the cobalt source available for the experiments performed, greater than $90 \%$ removal efficiency for both SER and CIT at a concentration of $1 \mathrm{mg} / \mathrm{L}$ was achieved in approximately $3 \mathrm{~min}$. While in the degradation of $1 \mathrm{mg} / \mathrm{L}$ SER using UV light, 50\% degradation efficiency was obtained after $58 \mathrm{~h}\left(\mathrm{t}_{1 / 2}=58 \mathrm{~h}\right)$ [38]. For an aqueous solution of CIT with a concentration 10 times lower 
i.e., $100 \mu \mathrm{g} / \mathrm{L}$, the application of UV light achieves practically complete degradation after about $20 \mathrm{~min}$, whereas when ozone is applied even after $90 \mathrm{~min}$ more than $20 \%$ of the initial amount of citalopram still remains in the solution [29].

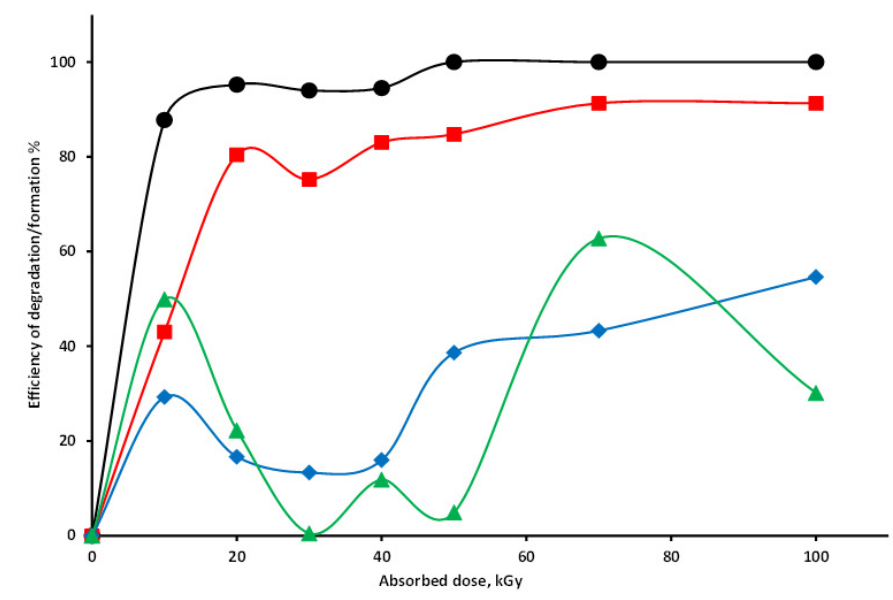

Figure 2. Efficiency of sertraline degradation and ionic products formation in aqueous solution saturated before irradiation with $\mathrm{N}_{2} \mathrm{O}-\bullet \cdot \mathrm{OH}$ radicals predominate: $(\bullet)$-sertraline $1 \mathrm{mg} / \mathrm{L}$ degradation,

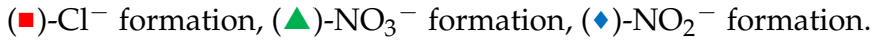

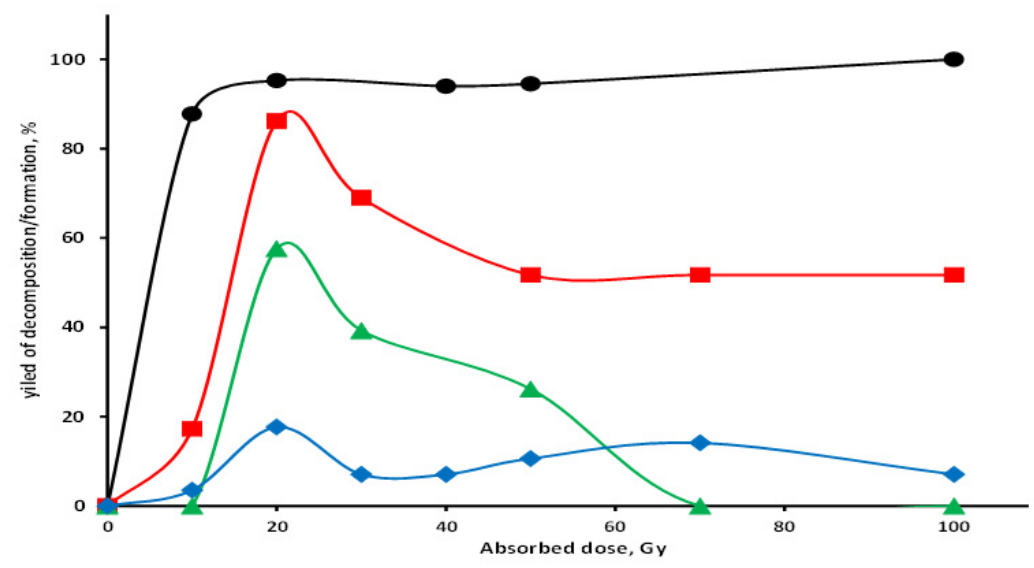

Figure 3. Efficiency of citalopram degradation and ionic products formation in aqueous solution saturated before irradiation with $\mathrm{N}_{2} \mathrm{O}-\bullet-\mathrm{OH}$ radicals predominate: $(\bullet)$-citalopram $1 \mathrm{mg} / \mathrm{L}$ degradation, $(\square)-\mathrm{F}^{-}$formation, $(\Delta)-\mathrm{NO}_{3}{ }^{-}$formation, $(\diamond)-\mathrm{NO}_{2}{ }^{-}$formation.

\subsection{Determination of Chemical Radiation Yield}

The irradiation yield can be described by the chemical yield of radiation (G-value), which is defined as the concentration of degraded or produced individuals upon absorption of $100 \mathrm{eV}$ of radiation energy:

$$
G=\frac{\Delta R N_{A}}{6.24 \times 10^{19} \times D}
$$

where, $\Delta R$ is the amount of degraded SER/CIT (mol/L), NA corresponds to Avogadro's constant of $6.02 \times 10^{23}$ (molecules mol/L), $D$ is the absorbed dose (kGy), and $6.02 \times 10^{19}$ is the conversion factor from $\mathrm{kGy}$ to $100 \mathrm{eV} / \mathrm{L}$. G values are given in $\mu \mathrm{mol} \mathrm{J}{ }^{-1}$, whereby,

$$
1 \text { molecules } \times /(100 \mathrm{eV})^{-1}=0.10364 \mu \mathrm{mol} \mathrm{J}^{-1}
$$

The $G$ values of the aqueous solution of SER and CIT irradiated under the conditions, where one selected product of water radiolysis dominate, are shown in Figure 4A,B. Ac- 
cording to the obtained values of the degradation efficiencies of both pharmaceuticals, the highest $G$ values were also obtained for conditions where ${ }^{\bullet} \mathrm{OH}$ radicals dominate during irradiation for both SER and CIT solutions. The $G$ values in both cases and for each process condition decreased with an increasingly absorbed dose, which is in agreement with other studies on radiolytic degradation of other contaminants [39]. The reason for the decrease in $G$ can be attributed to the increasing number of intermediates as the absorbed dose increases, and the intermediates may compete for reactive individuals with the degraded compound. In fact, for both pharmaceuticals, rapid decomposition was observed at relatively low absorbed doses under oxidizing conditions accompanied by relatively little interference of the intermediates formed at the beginning. The preference of oxidative conditions for the decomposition of sertraline and citalopram is also indicated by the significantly larger $G$ values for these conditions compared to conditions in which the solvated electron dominates.

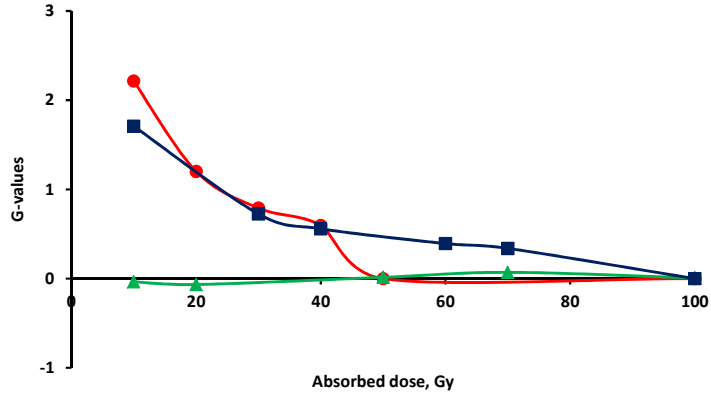

(A)

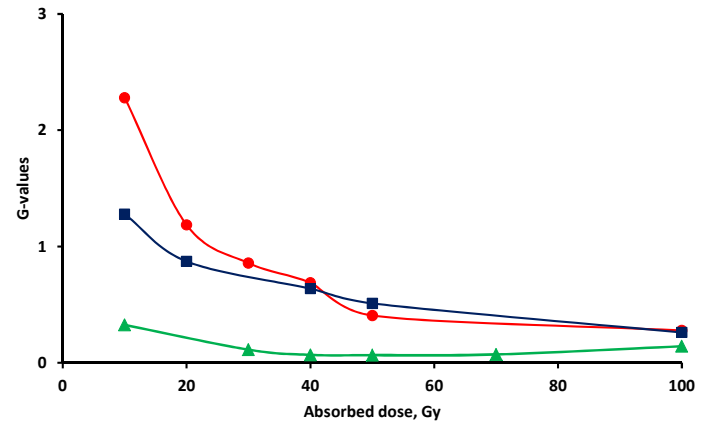

(B)

Figure 4. The G-values (radiation chemical yields) calculated at different radiation doses for decomposition of sertraline (A) and citalopram (B) at initial concentration $1 \mathrm{mg} / \mathrm{L}$ in different irradiation condition: $(\bullet)$ solution before irradiation saturated with $\mathrm{N}_{2} \mathrm{O},(\boldsymbol{\bullet})$ solution before irradiation aerated, (A) solution before irradiation saturated with Ar and in the presence of tert-butanol.

\subsection{Effect of $\mathrm{CO}_{3}{ }^{2-}, \mathrm{NO}_{3}{ }^{-}$and $\mathrm{HA}$}

Degradation of organic micropollutants, including psychotropic drugs, in fact concerns solutions of natural waters or wastewater. Therefore, an important addition to the ongoing research is to determine the effect of so-called free radical scavengers-substances, naturally occurring in the environment, that compete for reactive individuals with pollutants undergoing degradation, which are mainly anions and humic substances. Generally, in most cases these compounds negatively affect the degradation process [40], although positive or neutral effects on the radiation process have also been reported [41,42]. In the present work, the effect of the presence of $\mathrm{CO}_{3}{ }^{2-}, \mathrm{NO}_{3}{ }^{-}$, and humic substances on the degradation efficiency of SER and CIT in aqueous solutions with an initial concentration of $1 \mathrm{mg} / \mathrm{L}$ was determined. The concentration of added anions and humic substances for both SER and CIT was at $10 \mathrm{mg} / \mathrm{L}$. As shown in Figure 5A,B, the presence of natural free radical scavengers has little effect on the degradation efficiency of SER (Figure 5A), but a much greater effect was observed for CIT (Figure 5B). In the presence of humic substances, the degradation efficiency of sertraline in aqueous gamma-treated solution was practically unaffected. A slight approximate $10 \%$ reduction in degradation efficiency was observed in the presence of the addition of $10 \mathrm{mg} / \mathrm{L}$ carbonate and $10 \mathrm{mg} / \mathrm{L}$ nitrate in the lower dose range. However, for a dose of $100 \mathrm{~Gy}$ allowing for $100 \%$ degradation of $1 \mathrm{mg} / \mathrm{L}$ SER in ultrapure (Milli-Q) water, also in the presence of nitrates and carbonates, complete degradation of SER was obtained. In the case of CIT in the presence of $10 \mathrm{mg} / \mathrm{L}$ nitrates, the degradation efficiency is the same as in ultrapure (Milli-Q) water. A significant reduction in the degradation efficiency was observed in the presence of humic substances and carbonates; for the absorbed dose of $50 \mathrm{~Gy}$, the degradation efficiency was $70 \%$ in the presence of carbonates and $50 \%$ in the presence of humic substances, respectively. It 
was interesting to note that for a dose of $150 \mathrm{~Gy}$. this efficiency increased to $100 \%$ in the presence of humic substances. while for the system containing carbonates it was over $80 \%$ even after a maximum dose of 200 Gy. A greater impact on the efficiency of the process in the case of the used scavengers (HA, nitrate and carbonate $10 \mathrm{mg} / \mathrm{L}$ ) was observed for CIT. Most likely this is because there are significant differences in the magnitude of the rate constants SER and CIT with the hydroxyl radical and the electron. In the case of CIT, the values of these constants must be lower, and therefore the scavengers win the competition for hydroxyl radicals and we observe the inhibition of the CIT decomposition process. To confirm this hypothesis, in the next stage it is planned to determine the rate constants with the main products of water radiolysis using impulse radiolysis for both SER and CIT.

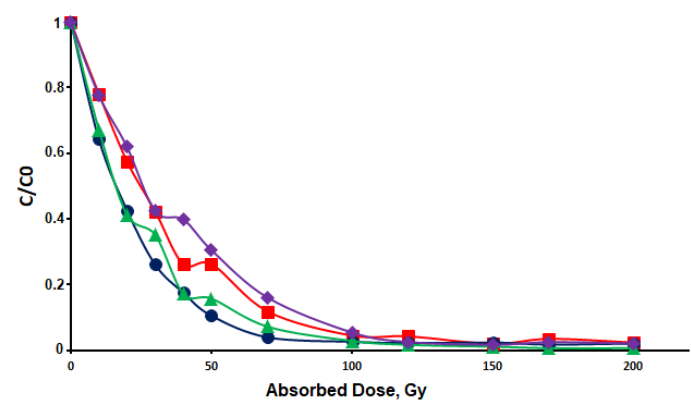

(A)

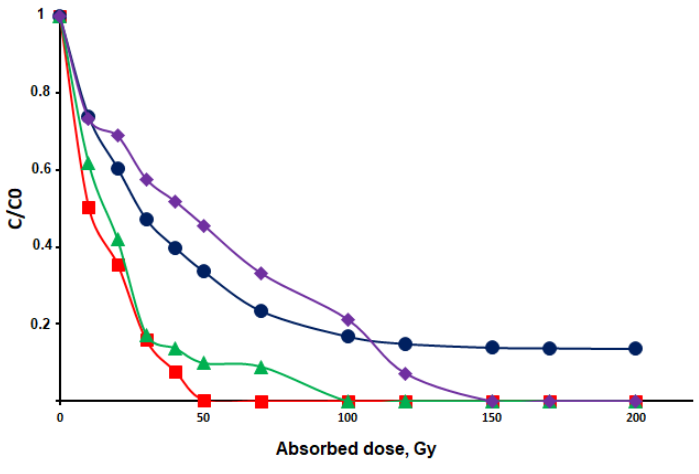

(B)

Figure 5. The yield of decomposition selected pharmaceuticals in the presence of hydroxyl radicals scavengers (A) ( $\bullet$ ) sertraline $1 \mathrm{mg} / \mathrm{L}$ in ultrapure (Milli-Q) water, $(\bullet)$ sertraline $1 \mathrm{mg} / \mathrm{L}$ in the presence of $10 \mathrm{mg} / \mathrm{L} \mathrm{CO}_{3}{ }^{2-},(\mathbf{A})$ sertraline $1 \mathrm{mg} / \mathrm{L}$ in the presence of $10 \mathrm{mg} / \mathrm{L} \mathrm{NO}_{3}{ }^{-},(\diamond)$ sertraline $1 \mathrm{mg} / \mathrm{L}$ in the presence of $10 \mathrm{mg} \mathrm{HA}$; (B) $(\bullet)$ citalopram $1 \mathrm{mg} / \mathrm{L}$ in ultrapure (Milli-Q) water, $(\bullet)$ citalopram 1 $\mathrm{mg} / \mathrm{L}$ in the presence of $10 \mathrm{mg} / \mathrm{L} \mathrm{CO}_{3}{ }^{2-},(\mathbf{\Delta})$ citalopram $1 \mathrm{mg} / \mathrm{L}$ in the presence of $10 \mathrm{mg} / \mathrm{L} \mathrm{NO}_{3}{ }^{-}$, ( ) citalopram $\mathrm{mg} / \mathrm{L}$ in the presence of $10 \mathrm{mg} \mathrm{HA}$.

Nevertheless, gamma radiation seems to be much more effective than UV radiation, after applying a dose of $200 \mathrm{~Gy}$. However, in each case we obtained more than $90 \%$ decay efficiency. It is important to add that to achieve a dose of $200 \mathrm{~Gy}$ under the conditions available for the experiment, about 5 min was sufficient. For the AOP process using UV light under optimal conditions in the presence of $10 \mathrm{mg} / \mathrm{L}$ humic substances, the $\mathrm{t}_{1 / 2}$ of decomposition of $1 \mathrm{mg} / \mathrm{L}$ SER decreased from $58 \mathrm{~h}$ to $7 \mathrm{~h}$ [38].

\subsection{SER and CIT Degradation in Surface Water}

Experiments on the effect of selected free radical scavengers have shown that in some situations their presence can affect the efficiency of the radiolytic degradation process carried out. Different water matrices, sometimes highly loaded, can cause SER and CIT degradation results to differ from those obtained for ultrapure water. The real situation in wastewater and natural water treatment is not simply the same as in clean water but is the result of a combination of various complex factors. The presence of unknown free radical scavengers reacting with target pollutants is a factor influencing the efficiency of radiolytic degradation [43]. The effect of three different natural matrices compared to solutions in ultrapure (Milli-Q) water on the radiolytic degradation efficiency of both SER and CIT drugs in aerated solutions was studied. Figure 6A,B shows the effect of natural matrices for both tested pharmaceuticals. These differences are significant in degradation efficiency and also different for SER and CIT for the same matrices. For example, to achieve an 80\% degradation efficiency of $1 \mathrm{mg} / \mathrm{L}$ SER in ultrapure (Milli-Q) water requires only a dose of 10 Gy. For effluent from Czajka WWTP, even after a dose of $200 \mathrm{~Gy}$, the degradation efficiency of $1 \mathrm{mg} / \mathrm{L}$ SER was less than $30 \%$. The effluent is theoretically after the treatment 
process and can be discharged to surface water into the river. Much better results were obtained for river matrices, where for water from the Vistula River for a dose of $200 \mathrm{~Gy}$ the sertraline degradation efficiency was over $80 \%$ and for water from the Rokitnica River about $60 \%$ (Figure 6A). As mentioned earlier, completely different results were obtained for $1 \mathrm{mg} / \mathrm{L}$ CIT in the same water matrices. In the effluent from Czajka WWTP, the degradation of the CIT occurred at a higher efficiency than in water, where about $80 \%$ efficiency was achieved after a dose of $10 \mathrm{~Gy}$, while in ultrapure (Milli-Q) water it was $40 \mathrm{~Gy}$. For the river matrices of both the Vistula and Rokitnica, similar results were obtained as for $1 \mathrm{mg} / \mathrm{L} \mathrm{SER,}$ this was about $80 \%$ degradation efficiency for the Vistula river after absorbing a dose of 200 Gy and about 50\% for the Rokitnica river. These examples clearly show the importance of a preliminary study of the irradiation conditions for a particular matrix type and a given target pollutant.

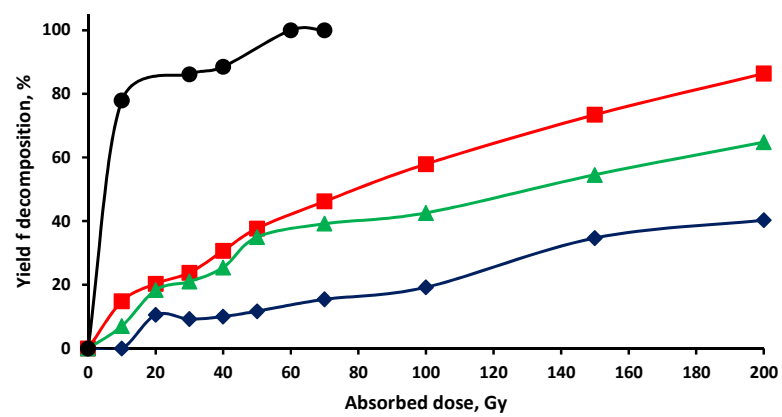

(A)

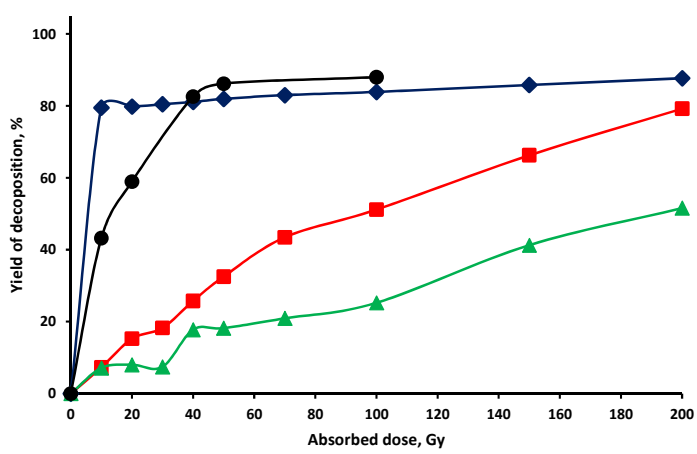

(B)

Figure 6. Decomposition of $1 \mathrm{mg} / \mathrm{L}$ solution of SER (A) and CIT (B) in different water matrices using gamma irradiation in aerated solution: $(\downarrow)$ effluent from Czajka Wastewater Treatment Works WWTP Watrsaw), (घ) Vistula river from Warsaw, $(\mathbf{\Delta})$ Rokitnica river from Czubin, $(\bullet)$ ultrapure (Milli-Q) water.

Comparing the results obtained for the decomposition of SER and CIT in natural matrices under gamma irradiation and other AOP processes (Table 1), it should be emphasized that the advantage of using radiation technology is the time of the process. Even when using a source such as in the carried out experiments, obtaining a dose of $200 \mathrm{~Gy}$ is less than $5 \mathrm{~min}$. In technological applications where radiation generated by an Electron Accelerator is used, this time is significantly reduced, with split seconds allowed to deliver doses of this order to the system. It should also be added that the radiation process does not require the addition of other chemicals supporting the decomposition process, such as $\mathrm{Cl}$ or $\mathrm{TiO}_{2}$, which additionally increase the costs of the process.

\subsection{Cytotoxicity Monitoring}

Literature data show that antidepressants, even at low concentrations of micrograms per liter or even nanograms per liter, can cause some undesirable effects on the aquatic environment. Pharmaceuticals of this type modify the regulation of neurotransmitters such as serotonin, norepinephrine, and dopamine and interfere with homeostasis in the central and peripheral nervous systems in both vertebrates and invertebrates. It has been shown that SSRI drugs can affect the reproduction of Ceriodaphnia dubia as demonstrated by reducing the number of neonates after exposure to $9 \mathrm{mg} / \mathrm{L}$ SER [44], a similar toxicity of SER has been shown for Daphnia magna [45]. SER as a new generation antidepressant is widely considered to be safe for human use; however, liver toxicity has been documented in preclinical studies [46]. With in vivo studies, rabbits treated orally with sertraline also showed significant morphometric and histological changes in the liver, such as hepatocyte necrosis and hydropathic degeneration [47]. Much literature data is available which indicates that certain antidepressants have growth inhibitory effects on many cancer cell 
lines. It was shown that for HepG2 liver cells, there was a concentration-dependent decrease in cell viability under the influence of sertraline, as measured by the MTS assay. At a concentration of $7.5 \mu \mathrm{M}$ sertraline, cell viability was reduced to approximately $83 \%$ compared to the DMSO control. Moreover, HepG2 viability detected by MTS decreased to about $23 \%$ when cells were treated with $15 \mu \mathrm{M}$ sertraline, indicating that there was significant inhibition of growth and cell damage [48]. In the case of MCF-7 breast cancer cells, a much stronger effect was observed for sertraline, where the IC50 was approx. $16 \mu \mathrm{M}$, respectively, than for citalopram [49]. CIT was found to be as poorly toxic to primary cultures of abalone (Haliotis tuberulata) hemocytes exposed to the pharmaceutical for $48 \mathrm{~h}$, with IC50 determined to be at the level $\mathrm{mg} / \mathrm{L}$ [50]. On the other hand, it has been confirmed that for higher concentrations of CIT $(10 \mathrm{mg} / \mathrm{kg})$ there is a risk of hepatotoxicity, which is expressed by the occurrence of hepatic cell necrosis, asymmetry of hepatic nuclei and displacement of hepatic cord cells (hepatocytes) [51]. In the present study, cytotoxicity of SER and CIT pharmaceuticals was determined towards two selected commercially available liver HepG2 and colon Caco2 cell lines. The results obtained for SER towards HepG2 and Caco2 over a wide range of concentrations from 0 to $30 \mu \mathrm{M}$ are shown in Figure $7 \mathrm{~A}, \mathrm{C}$. For both HepG2 and Caco2, an approximately 20\% decrease in cell survival after a $24 \mathrm{~h}$ incubation period is observed for an initial SER concentration of $6.25 \mu \mathrm{M}$. This agrees with data obtained previously for HepG2 cells treated with SER [48]. It was found that for SER concentrations above $12.5 \mu \mathrm{M}$, which corresponds to $3.8 \mathrm{mg} / \mathrm{L}$ for both HepG2 after a 48-h incubation period and $\mathrm{Caco} 2$ after a 24-h incubation period, an acute cytotoxic effect is observed, and cell survival is below $20 \%$ compared to the control solution. As expected from previous literature reports where the concentration of CIT causing liver cell death was determined to be $500 \mu \mathrm{M}$ [52], CIT was significantly less toxic than SER for selected cell lines. Our results obtained in the concentration range from 0 to $400 \mu \mathrm{M}$ are presented in Figure 8A,B. In the case of CIT, HepG2 cells were more sensitive to the pharmaceutical, for which $50 \%$ survival was observed for a concentration of $75 \mu \mathrm{M}$ after a $48 \mathrm{~h}$ incubation period. While for $\mathrm{Caco} 2$ such an effect could be observed for a concentration of $100 \mu \mathrm{M}$ only after a $72 \mathrm{~h}$ incubation time. Considering the concentration levels (usually $\mathrm{ng} / \mathrm{L}$ ) at which both pharmaceuticals are identified in natural waters and wastewater, it can be assumed that these are safe levels for selected cell lines. To demonstrate the high efficiency of using radiation technologies, in this case gamma radiation to remove residues of selected ADs, the HepG2 and $\mathrm{Caco} 2$ lines were exposed to the irradiated SER solution at a higher initial concentration. Aqueous solutions of SER with an initial concentration of $10 \mathrm{mg} / \mathrm{L}$ (equivalent to $32.65 \mu \mathrm{M}$-SER), were irradiated in a cobalt gamma source in a dose range up to $300 \mathrm{~Gy}$. As indicated previously (Figure 1A), complete degradation of $10 \mathrm{mg} / \mathrm{L}$ SER was achieved after a dose of $200 \mathrm{~Gy}$ was delivered to the system. The toxicity monitoring performed for such a high concentration of SER, showing that more than $90 \%$ survival for Caco 2 cells and almost $100 \%$ for HepG2 cells was achieved already after a dose of $20 \mathrm{~Gy}$ (Figure 7B,D). The results obtained are very promising. They demonstrate that even for such high concentrations of SER, or possibly the greater synergistic effects observed in the presence of other contaminants such as the previously mentioned microplastic [28], reduced cytotoxicity can be expected after degradation using relatively low doses of ionizing radiation.

\subsection{Preliminary Identification of Degradation Product}

Our previously described experiments on the decomposition of SER and CIT under the conditions of dominance of one selected product of water radiolysis showed that the decomposition of both SER and CIT occurs with the highest efficiency in the presence of hydroxyl radicals. Considering the complicated chemical structure of SER and CIT as well as the high reactivity of hydroxyl radicals, many potential sites of attack of the hydroxyl radical on the molecule of the selected pharmaceutical have been postulated [53]. It has been shown that the products formed in the photocatalytic degradation of SER include its hydroxyl derivatives monoxydroxysertraline (m/z 322.0768), dihydroxysertraline $\mathrm{m} / 338.0715$ and 
trihydroxysertraline $\mathrm{m} / \mathrm{z} 354.0661$ [36,38]. We also confirmed the formation of trihydoxysertraline, dihydroxysertraline and monohydroxysertraline during gamma irradiation of SER aqueous solutions (Figure 9). Other identified products of radiolytic degradation of SER are summarized in Table 2, which include dehalogenation products and compounds with lower molar masses.

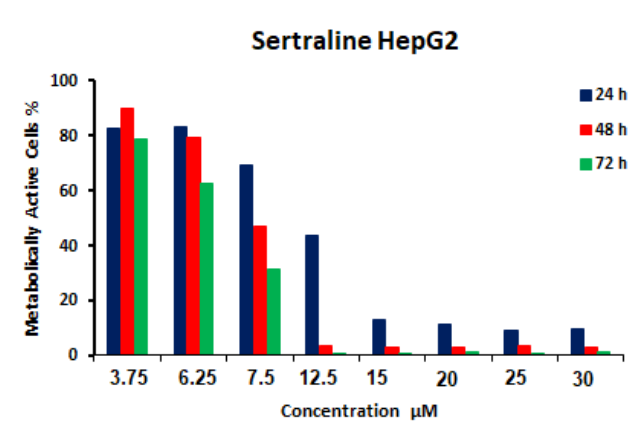

(A)

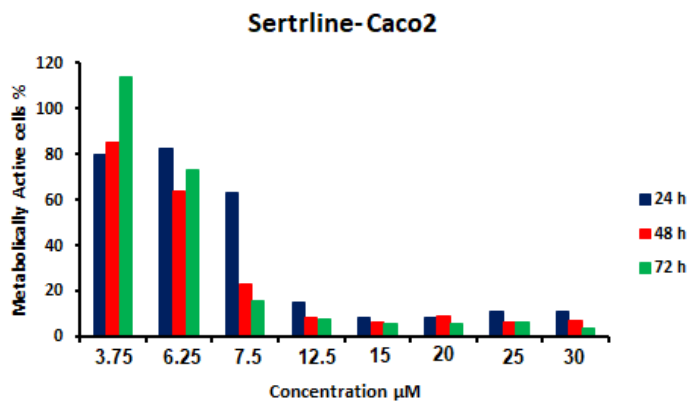

(C)

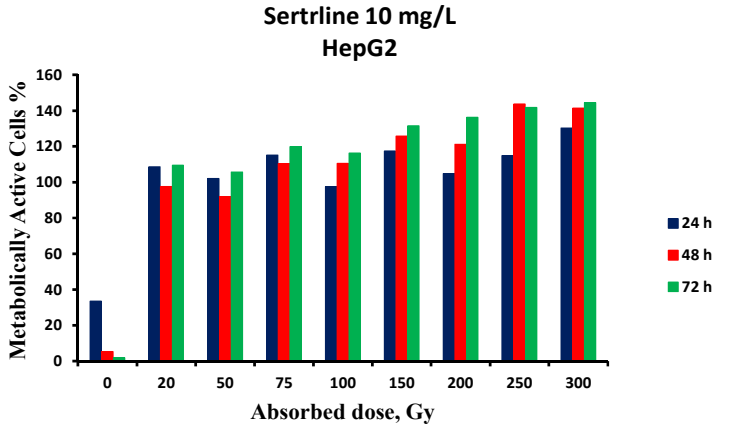

(B)

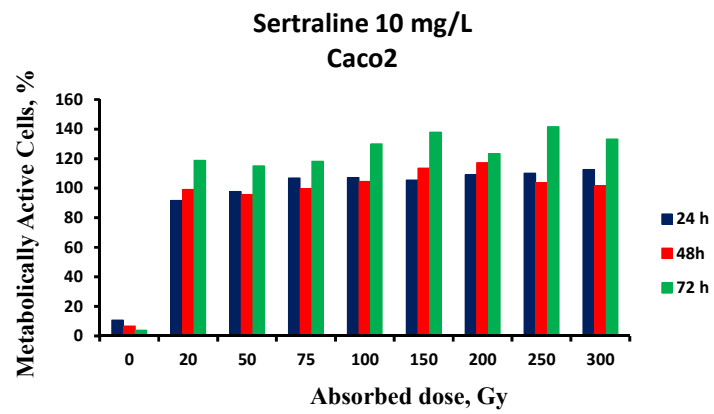

(D)

Figure 7. Cytotoxicity monitoring (A) sertraline against HepG2 (B) sertraline $10 \mathrm{mg} / \mathrm{L}$ after gamma irradiation towards HepG2 (C) sertraline towards Caco2 (D) sertraline $10 \mathrm{mg} / \mathrm{L}$ towards gamma irradiation towards Caco2.

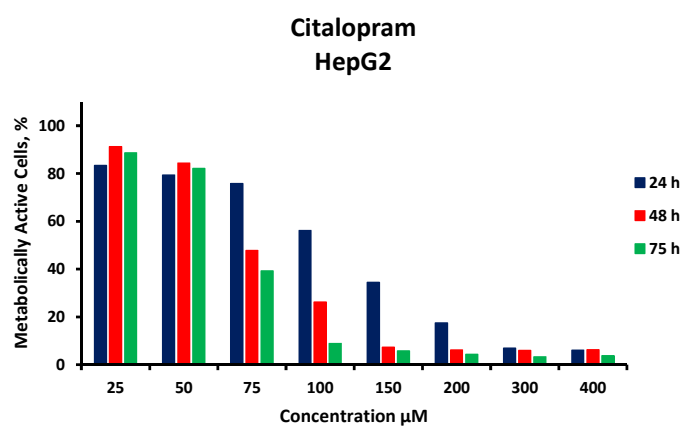

(A)

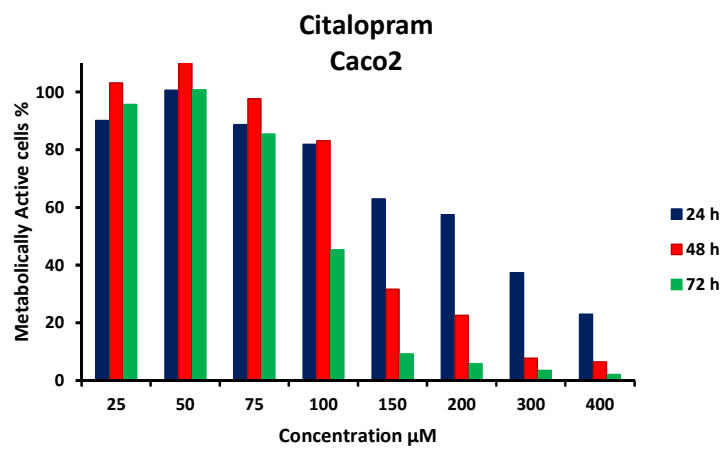

(B)

Figure 8. Cytotoxicity monitoring (A) citalopram against HepG2 (B) citalopram towards Caco2. 


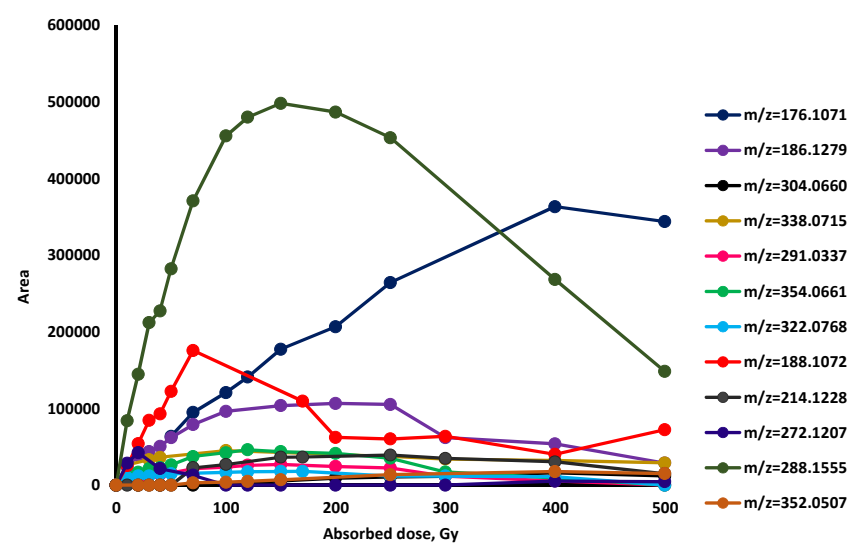

Figure 9. Formation of selected radiolytic degradation product of sertraline.

Table 2. Detected products of sertraline degradation.

No.


Table 2. Cont.

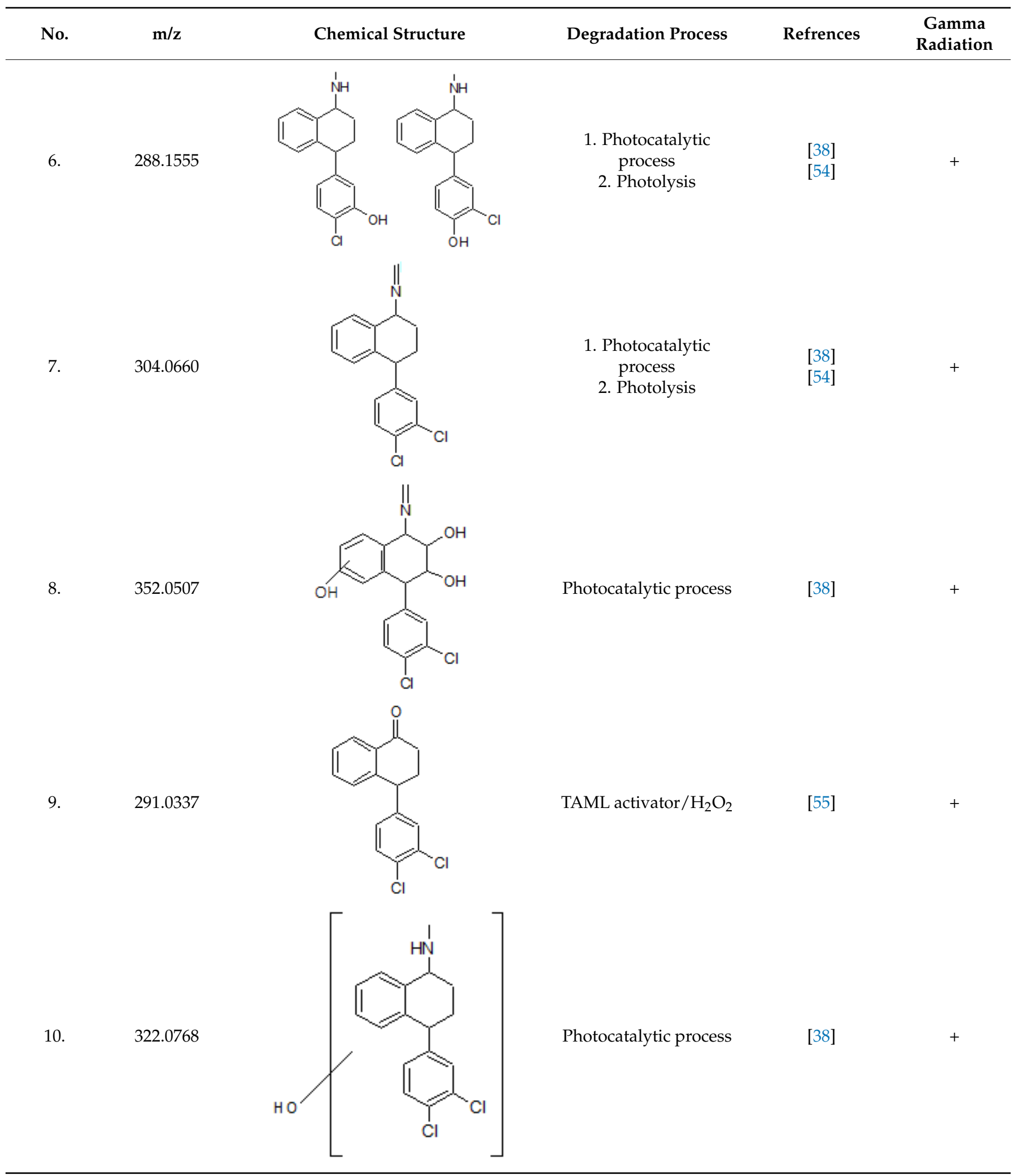


Table 2. Cont.

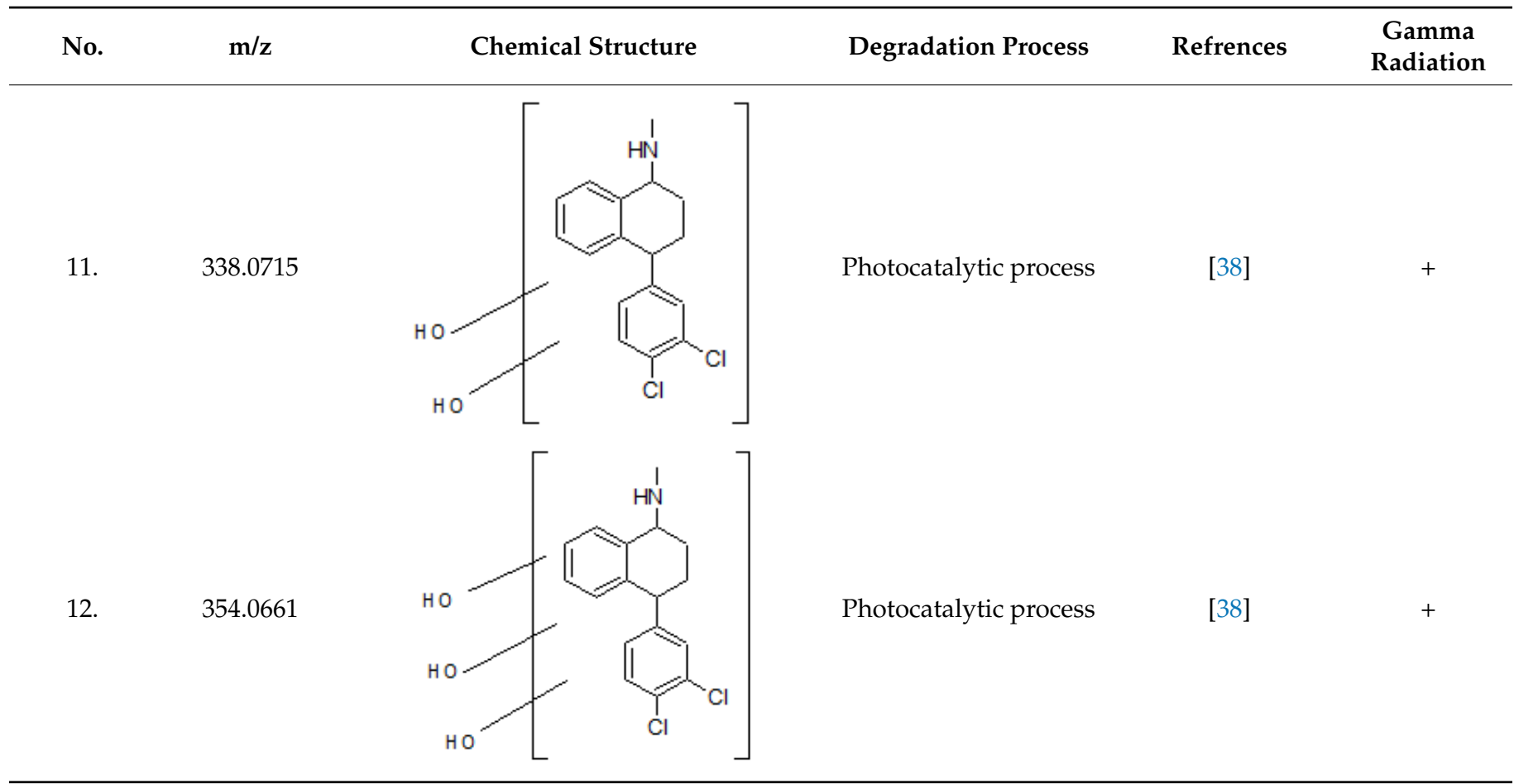

In the case of CIT biodegradation, the main reactions that the pharmaceutical undergoes during degradation are mainly oxidative reactions such as hydroxylation, oxidation, $\mathrm{N}$-oxidation and $\mathrm{N}$-demethylation, as well as nitrile hydrolysis and amide hydrolysis [56]. The literature data also demonstrate that in the photocatalytic process, hydroxylation also involves the furan ring and the alkyl chain as indicated by the formation of the dihydroxyl product $\mathrm{C}_{20} \mathrm{H}_{22} \mathrm{O}_{3} \mathrm{~N}_{2} \mathrm{~F}$ (m/z 357.1618) [36]. In the degradation of CIT in AOP processes based on the use of Ozone, $\mathrm{ClO} 2, \mathrm{UV}$ and oxidative Fenton, the authors have shown the formation of degradation products that [29]: (1) $\left(\mathrm{C}_{19} \mathrm{H}_{20} \mathrm{~N}_{2} \mathrm{OF} \mathrm{m} / \mathrm{z}\right.$ 311.1560. It suggests the loss of a methyl group by the CIT molecule, (2) $\left(\mathrm{C}_{20} \mathrm{H}_{23} \mathrm{~N}_{2} \mathrm{O}_{2} \mathrm{~m} / \mathrm{z}=323.1393\right)$ replacement of the $\mathrm{F}$ atom by an oxygen and hydrogen atom (3) $\left(\mathrm{C}_{20} \mathrm{H}_{22} \mathrm{~N}_{2} \mathrm{O}_{2} \mathrm{~F} \mathrm{~m} / \mathrm{z}=341.1658\right.$ an additional oxygen atom is attached to the molecule (4) $\mathrm{m} / \mathrm{z} 339.1506$ transformation products, and based on its $\mathrm{ms} / \mathrm{ms}$ spectra, they postulated formation butyrolactone derivatives. In our preliminary studies the formation of these products was also found in Figure 10 and Table 3. Based on the products identified, the authors assumed that hydroxylation occurred on the benzene ring along with the detachment of the fluorine atom, as already described for the photocatalytic degradation of similar structures [38]. Most of the initially identified radiolytic degradation products of SER and CIT are fully compatible with the products obtained in the photocatalytic process, some of them were also identified in biodegradation processes. Based on this, we made the initial assumption that the decay mechanism of both SER and CIT under gamma irradiation follows a similar path. 


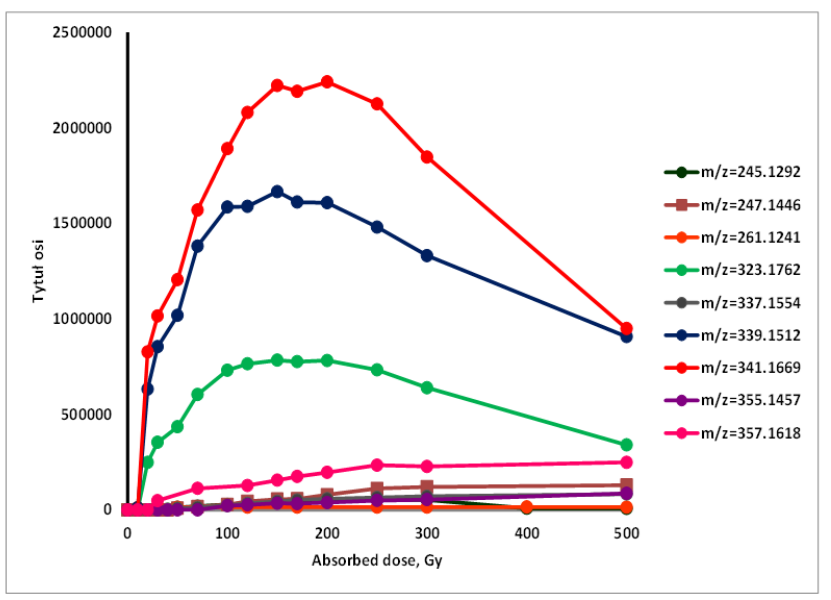

Figure 10. Formation of selected radiolytic degradation product of citalopram.

Table 3. Detected products of citalopram degradation.

\begin{tabular}{|c|c|c|c|c|c|}
\hline No. & $\mathrm{m} / \mathrm{z}$ & Chemical Structure & Degradation Process & References & Gamma \\
\hline 1. & 245.1292 & & $\begin{array}{l}\text { UV-radiation } \\
\text { Photocatalytic degradation } \\
\text { Photodegradation in the } \\
\text { presence of WEOM (Water } \\
\text { Extractable Organic Matter) }\end{array}$ & $\begin{array}{l}{[34]} \\
{[37]} \\
{[54]}\end{array}$ & + \\
\hline 2. & 247.1446 & & Photocatalytic degradation & [37] & + \\
\hline 3. & 261.1241 & $\mathrm{H} 3 \mathrm{C}$ & Photocatalytic degradation & [37] & + \\
\hline 4. & 323.1762 & $\mathrm{H} 3 \mathrm{C}$ & $\begin{array}{l}\text { Photocatalytic degradation } \\
\text { Photodegradation in the } \\
\text { presence of WEOM (Water } \\
\text { Extractable Organic Matter) }\end{array}$ & $\begin{array}{l}{[37]} \\
{[54]}\end{array}$ & + \\
\hline 5. & 337.1554 & & Photocatalytic degradation & [37] & + \\
\hline
\end{tabular}


Table 3. Cont.

\begin{tabular}{|c|c|c|c|c|c|}
\hline No. & $\mathbf{m} / \mathbf{z}$ & Chemical Structure & Degradation Process & References & Gamma \\
\hline 6. & 339.1512 & $\underset{\mathrm{H} 3 \mathrm{C}}{1}$ & $\begin{array}{l}\mathrm{UV}, \mathrm{Cl}, \mathrm{H}_{2} \mathrm{O} \\
\text { Photocatalytic degradation } \\
\text { Photodegradation in the } \\
\text { presence of WEOM (Water } \\
\text { Extractable Organic Matter) }\end{array}$ & $\begin{array}{l}{[34]} \\
{[37]} \\
{[54]}\end{array}$ & + \\
\hline 7. & 341.1669 & $\prod_{\mathrm{H} 3 \mathrm{C}}$ & $\begin{array}{l}\text { UV } \\
\text { Photocatalytic degradation } \\
\text { Photodegradation in the } \\
\text { presence of WEOM (Water } \\
\text { Extractable Organic Matter) }\end{array}$ & $\begin{array}{l}{[34]} \\
{[37]} \\
{[54]}\end{array}$ & + \\
\hline 8. & 355.1457 & $\mathrm{H} 3 \mathrm{C}$ & $\begin{array}{l}\mathrm{Cl} \\
\text { Photocatalytic degradation } \\
\text { Photodegradation in the } \\
\text { presence of WEOM (Water } \\
\text { Extractable Organic Matter }\end{array}$ & $\begin{array}{l}{[34]} \\
{[37]} \\
{[54]}\end{array}$ & + \\
\hline 9. & 357.1618 & $\mathrm{H} 3 \mathrm{C}$ & Photocatalytic degradation & [37] & + \\
\hline
\end{tabular}

\section{Conclusions}

For the first time, gamma radiation was used to the degradation of selected psychotropic drugs SER and CIT from natural waters. The obtained results were satisfactory, and for relatively low doses of ionizing radiation (max. $500 \mathrm{~Gy}$ ), practically complete degradation was obtained both in pure aqueous solutions and surface waters. It was shown that the free radical scavengers commonly found in water, i.e., carbonyls, nitrates, and humic acid in concentrations ten times higher than those of the drugs studied, have little effect on the degradation efficiency. An attempt was also made to identify the products formed in the degradation of sertraline and citalopram, which allowed for a preliminary assumption that the degradation of these drugs to a large extent proceeds in a mode similar to the photocatalytic process. Cytotoxicity monitoring showed that even for high drug concentrations, in the case of SER $10 \mathrm{mg} / \mathrm{L}$, a complete reduction of toxicity was observed after a dose of $20 \mathrm{~Gy}$ was delivered to the system. A very important thing to mention about the degradation process using radiation technologies is the time. As shown in the information presented, using gamma radiation takes only a few minutes to achieve satisfactory results in the purification of water from AD's residues. It is worth mentioning that this time can be significantly reduced after the application of an electron beam. In comparison with the data in Table 1 for other AOP processes, this will be a considerable argument in favor of radiation technologies.

Author Contributions: Conceptualization, A.B.-C.; methodology, A.B.-C.; A.M.-P.; software, A.B.-C.; validation, A.B.-C.; formal analysis, A.B.-C.; A.M.-P.; investigation, A.B.-C.; M.P.; K.W.; resources, A.B.-C.; data curation, A.B.-C.; M.P.; writing-Original draft preparation, A.B.-C.; writing-Review and editing, A.B.-C.; visualization, A.B.-C.; supervision, A.B.-C.; A.M.-P.; project administration, 
A.B.-C.; funding acquisition, A.B.-C. All authors have read and agreed to the published version of the manuscript.

Funding: This project has received funding from the European Union's Horizon 2020 Research and Innovation programe under Grant Agreement No 101004730. Presented investigation were also supported by the Polish Ministry of Education and Science in the frame of co-funding the project I.FAST "Innovation Fostering in Accelerator Science and Technology".

Institutional Review Board Statement: Not applicable.

Informed Consent Statement: Not applicable.

Data Availability Statement: Not applicable.

Conflicts of Interest: The authors declare no conflict of interest.

\section{References}

1. Virkutyte, J.; Varma, R.S.; Jegatheesan, V. Treatment of Micropollutants in Water and Wastewater; IWA Publishing: London, UK, 2010.

2. $\quad$ Brauer, R.; Alfageh, B.; Blais, J.E.; Chan, E.W.; Chui, C.S.L.; Hayes, J.F.; Man, K.K.C.; Lau, W.C.Y.; Yan, V.K.C.; Beykloo, M.Y.; et al. Psychotropic medicine consumption in 65 countries and regions, 2008-2019: A longitudinal study. Lancet Psychiatry 2021, 8 , 1071-1082. [CrossRef]

3. Rabeea, S.A.; Merchant, H.A.; Khan, M.U.; Kow, C.S.; Hasan, S.S. Surging trends in prescriptions and costs of antidepressents in England amid COVID-19. DARU J. Pharm. Sci. 2021, 29, 217-221. [CrossRef]

4. $\quad$ Cipriani, A.; Furukawa, T.A.; Salanti, G.; Chaimani, A.; Atkinson, L.Z.; Ogawa, Y.; Leucht, S.; Ruhe, H.G.; Turner, E.H.; Higgins, J.P.T.; et al. Comparative efficacy and acceptability of 21 antidepressant drugs for acute treatment of adults with major depressive disorder. A systematic review and network meta-analysis. Lancet 2018, 391, 1357-1366. [CrossRef]

5. Sheffler, Z.M.; Abdijadid, S. Antidepressants. In StatPearls; National Center for Biotechnology Information, U.S. National Library of Medicine 8600 Rockville Pike, Treasure Island (FL); StatPearls Publishing: Bethesda, MD, USA, 2021.

6. Lalji, H.M.; McGrogan, A.; Bailey, S.J. An analysis of antidepressant prescribing trends in England 2015-2019. J. Affect. Disord. Rep. 2021, 6, 100205. [CrossRef] [PubMed]

7. Ding, R.; Wang, Y.; Ye, X.; Zhu, D.; Shi, X.; He, P. Antidepressant use and expenditure in the treatment of patients with depression: Evidence from China urban medical claim data. J. Affect. Disord. 2022, 296, 603-608. [CrossRef] [PubMed]

8. Giebułtowicz, J.; Nałęcz-Jawecki, G. Occurrence of antidepressant residues in the sewage-impacted Vistula and Utrata rivers and in tap water in Warsaw (Poland). Ecotoxicol. Environ. Saf. 2014, 104, 103-109. [CrossRef] [PubMed]

9. Golovko, O.; Kumar, V.; Fedorova, G.; Randak, T.; Grabic, R. Seasonal changes in antibiotics, antidepressants/psychiatric drugs, antihistamines and lipid regulators in a wastewater treatment plant. Chemosphere 2014, 111, 418-426. [CrossRef]

10. Evans, S.E.; Davies, P.; Lubben, A.; Kasprzyk-Hordern, B. Determination of chiral pharmaceuticals and illicit drugs in wastewater and sludge using microwave assisted extraction, solid-phase extraction and chiral liquid chromatography coupled with tandem mass spectrometry. Anal. Chim. Acta 2015, 882, 112-126. [CrossRef]

11. Silva, L.J.G.; Pereira, A.M.P.T.; Meisel, L.M.; Lino, C.M.; Pena, A. A one-year follow-up analysis of antidepressants in Portuguese wastewaters: Occurrence and fate, seasonal influence and risk assessment. Sci. Total Environ. 2014, 490, 279-287. [CrossRef]

12. Writer, J.H.; Ferrer, I.; Barber, L.B.; Thurman, E.M. Widespread occurrence of neuroactive pharmaceuticals and metabolites in 24 Minnesota rivers and wastewaters. Sci. Total Environ. 2013, 461, 519-527. [CrossRef]

13. Fick, J.; Soderstrom, H.; Lindberg, R.H.; Phan, C.; Tysklind, M.; Larsson, D.G.J. Contamination of surface ground and drinking water from pharmaceutical production. Environ. Toxicol. Chem. 2009, 28, 2522-2527. [CrossRef]

14. Arnnok, P.; Singh, R.R.; Burakham, R.; Perez-Fuenteja, A.; Aga, D.S. Selective uptake and bioacumulation of antidepressants in fish from effluent-impacted Niagara River. Environ. Sci. Technol. 2017, 51, 10652-10662. [CrossRef]

15. Brooks, B.W.; Chambliss, C.K.; Stanley, J.K.; Ramirez, A.; Banks, K.E.; Johnson, R.D.; Lewis, R.J. Determination of select antidepressants in fish from an effluent-dominated stream. Environ. Toxicol. Chem. 2005, 24, 464-469. [CrossRef] [PubMed]

16. Kumer, A.; Xagogaraki, I. Pharmaceuticals, personal care products and endocrine disrupting chemicals IN US surface and finished drinking waters: A proposed ranking system. Sci. Total Environ. 2010, 408, 5972-5989. [CrossRef] [PubMed]

17. Metcalfe, C.D.; Chu, S.; Judt, C.; Li, H.; Oakes, K.D.; Servos, M.R.; Andrews, D.M. Antidepressants and their metabolites in municipal wastewater, and downstream exposure in an urban watershed. Environ. Toxicol. Chem. 2010, 29, 79-89. [CrossRef] [PubMed]

18. Tarcomnicu, I.; van Nuijs, A.L.N.; Simons, W.; Bervoets, L.; Blust, R.; Jorens, P.G.; Neels, H.; Covaci, A. Simultaneous determination of 15 top-prescribed pharmaceuticals and their metabolites in influent wastewater by reversed-phase liquid chromatography coupled to tandem mass spectrometry. Talanta 2011, 83, 795-803. [CrossRef]

19. Degreef, M.; van Nuijs, A.L.N.; Maudens, K.E. Validation of simple, fast liquid chromatography-tandem mass spectrometry method for the simultaneous quantification of 40 antidepressant drugs or their metabolites in plasma. Clin. Chim. Acta 2018, 485, 243-257. [CrossRef] 
20. Ma, W.; Gao, X.; Guo, H.; Chen, W. Determination of 13 antidepressants in blood by UPLC-MS/MS with supported liquid extraction pretreatment. J. Chromatogr. B 2021, 1171, 122608. [CrossRef]

21. Kinyua, J.; Covaci, A.; Maho, W.; McCall, A.K.; Neels, H.; van Nuis, A.L. Sewage-based epidemiology in monitoring the use new psychoactive substances: Validation and application of an analytical method using LC-MS/MS. Drug Test. Anal. 2015, 7, 812-818. [CrossRef]

22. Lin, W.; Huang, Z.; Gao, S.; Luo, Z.; An, W.; Li, P.; Ping, S.; Ren, Y. Evaluating the stability of prescription drugs in municipal wastewater and sewers based on wastewater-based epidemiology. Sci. Total Environ. 2021, 754, 142414. [CrossRef]

23. Hua, F.L.; Tsang, Y.F.; Chua, H. Progress of water pollution control in Hong Kong. Aquat. Ecosyst. Health Manag. 2008, 11, 225-229. [CrossRef]

24. Tsang, Y.F. Environmental protection and pollution management in China. In The Entrepreneurial Rise in Southeast Asia: The Quadruple Helix Influence on Technological Innovation; Sindakis, S., Walter, C., Eds.; Palgrave Macmillan: New York, NY, USA, 2015.

25. Behera, S.K.; Kim, H.W.; Oh, J.E.; Park, H.S. Occurrence and removal of antibiotics, hormones and several other pharmaceuticals and other in wastewater treatment plants of the largest industrial city of Korea. Sci. Total Environ. 2011, 409, 4351-4360. [CrossRef]

26. Styrishave, B.; Halling-Sorensen, B.; Ingerslev, F. Environmental risk assessment of three selective serotonin reuptake inhibitors in the aquatic environment: A case study including a cocktail scenario. Environ. Toxicol. Chem. 2011, 30, 254-261. [CrossRef]

27. O'Flynn, D.; Lawler, J.; Yusuf, A.; Parle-McDermott, A.; Harold, D.; Mc Cloughlin, T.; Holland, L.; Regan, F.; White, B. A review of pharmaceutical occurrence and pathways in the aquatic environment in the context of a changing climate and the COVID-19 pandemic. Anal. Methods 2021, 13, 575-594. [CrossRef]

28. Shi, W.; Han, Y.; Sun, S.; Tang, Y.; Zhou, W.; Du, X.; Liu, G. Immunotoxicites of microplastics and sertraline, alone and in combination, to a bivalent species: Size-dependent interaction and potential toxication mechanism. J. Hazard. Mater. 2020, 396, 122603. [CrossRef]

29. Horsing, M.; Kosjek, T.; Andersen, H.R.; Heath, E.; Ledin, A. Fate of citalopram during water treatemnt with $\mathrm{O}_{3}, \mathrm{ClO}_{2}, \mathrm{UV}_{\text {and }}$ fenton oxidation. Chemosphere 2012, 89, 129-135. [CrossRef]

30. Rejek, M.; Grzechulska-Damszel, J. Degradation of sertraline in water by suspended and supported TiO 2 . Pol. J. Chem. Technol. 2018, 20, 107-112. [CrossRef]

31. Pliego, G.; Xekoukoulotakis, N.; Venieri, D.; Zazo, J.A.; Casas, J.A.; Rodriguez, J.J.; Mantzavinos, D. Complete degradation of the persistent anti-depressant sertraline in aqueous solution by solar photo-Fenton oxidation. J. Chem. Technol. Biotechnol. 2014, 89, 814-818. [CrossRef]

32. de Lima Perini, J.A.; Nogueira, R.F.P. Zero-valent iron mediated degradation of sertraline-effect of $\mathrm{H}_{2} \mathrm{O}_{2}$ addition and application to sewage treatment plant effluent. J. Chem. Technol. Biotechnol. 2016, 91, 276-282. [CrossRef]

33. Spina, M.; Venancio, W.; Rodrigues-Silva, C.; Pivetta, R.C.; Diniz, V.; Rath, S.; Guimaraes, J.R. Degradation of antidepressant pharmaceuticals by photoperoxidation in diverse water matrices: A highlight in the evaluation of acute and chronic toxicity. Environ. Sci. Pollut. Res. 2021, 28, 24034-24045. [CrossRef] [PubMed]

34. Osawa, R.A.; Carvalho, A.P.; Monteiro, O.C.; Oliveira, M.C.; Florencio, M.H. Transformation products of citalopram: Identification, wastewater analysis and in silico toxicological assessment. Chemosphere 2019, 217, 858-868. [CrossRef]

35. Lejeunesse, A.; Blais, M.; Barbeau, B.; Sauve, S.; Gagnon, C. Ozone oxidation of antidepressants in wastewater-Treatment evaluation and characterization of new by-products by LC-QTOF MS. Chem. Cent. J. 2013, 7, 15-25. [CrossRef]

36. Gornik, T.; Vozic, A.; Heath, E.; Trontelj, J.; Roskar, R.; Zigon, D.; Vione, D.; Kosjek, T. Determination and photodegradation of sertraline residues in aqueous environment. Environ. Pollut. 2020, 256, 113431. [CrossRef]

37. Jimenez-Holgado, C.; Calza, P.; Fabbri, D.; Bello, F.D.; Medana, C.; Sakkas, V. Investigation of the aquatic photolytic and photocatalytic degradation of citalopram. Molecules 2021, 26, 5331. [CrossRef]

38. Calza, P.; Jiminez-Holgado, C.; Coha, M.; Chrimatopoulos, C.; Bello, F.D.; Medana, C.; Sakkas, V. Study of the photoinduced transformations of sertralinie in aqueous media. Sci. Total Environ. 2021, 756, 143805. [CrossRef] [PubMed]

39. Trojanowicz, M.; Bojanowska-Czajka, A.; Szreder, T.; Męczyńska-Wielgosz, S.; Bobrowski, K.; Fornal, E.; Nichipor, H. Application of ionizing radiation for removal of endocrine disrupotor bisphenol A from waters and wastewaters. Chem. Eng. J. 2021, 403, 126169. [CrossRef]

40. Buxton, G.V.; Greenstock, C.L.; Helman, W.P.; Ross, A.B. Critical Review of rate constants for reaction of hydrated electrons, hydrogen atoms and hydroxyl radicals $\mathrm{OH} / \mathrm{O}$ in aqueous solution. J. Phys. Chem. Ref. Data 1988, 17, 513-886. [CrossRef]

41. Bojanowska-Czajka, A.; Kciuk, G.; Gumiela, M.; Borowiecka, S.; Nałęcz-Jawecki, G.; Koc, A.; Garcia-Reyes, J.F.; Ozbay, D.S.; Trojanowicz, M. Analytical, toxicological and kinetic investigation of decomposition of the drug diclofenac in waters and wastes using gamma radiation. Environ. Sci. Pollut. Res. 2015, 22, 20255-20270. [CrossRef] [PubMed]

42. Basfar, A.A.; Mohamed, K.A.; Al-Abduly, A.J.; Al-Shahrani, A.A. Radiolytic degradation of atrazine aqueous solution containing humic substances. Ecotoxicol. Environ. Saf. 2009, 72, 948-953. [CrossRef] [PubMed]

43. Trojanowicz, M.; Bobrowski, K.; Szreder, T.; Bojanowska-Czajka, A. Gamma-ray, X-ray and electron beam processes. In Advanced Oxidation Processes for Wastewater Treatment; Ameta, S.C., Ameta, R., Eds.; Elsevier: Amsterdam, The Netherlands, 2018 ; pp. 257-331.

44. Henry, T.B.; Kwon, J.-W.; Armbrust, K.L.; Black, M.C. Acute and chronic toxicity of five selective serotonin reuptake inhibitors in Ceriodaphnia dubia. Environ. Toxicol. Chem. 2004, 23, 2229-2233. [CrossRef] [PubMed]

45. Minagh, E.; Hernan, R.; O'Rourke, K.; Lyng, F.M.; Davoren, M. Aquatic ecotoxicity of the selective serotonin reuptake inhibitor sertraline hydrochloride in a battery of fresh water test species. Ecotoxicol. Environ. Saf. 2009, 72, 434-440. [CrossRef] [PubMed] 
46. de Gage, S.B.; Collin, C.; Le-Tri, T.; Pariente, A.; Begaud, B.; Verdoux, H.; Dray-Spira, R.; Zureik, M. Antidepressants and Hepatotoxicity: A short study among 5 million individuals registers in the French National Health Insurance. CNS Drugs 2018, 32, 673-684. [CrossRef] [PubMed]

47. Almansour, M.I.; Jarrar, Y.B.; Jarrar, B.M. In vivo investigation on the chronic hepatotoxicity induced by sertraline. Environ. Toxicol. Pharmacol. 2018, 61, 107-115. [CrossRef]

48. Chen, S.; Wu, Q.; Li, X.; Li, D.; Fan, M.; Ren, Z.; Bryant, M.; Mei, N.; Ning, B.; Guo, L. The role of hepatic cytochrome P450s in the cytotoxicity of sertraline. Arch. Toxicol. 2020, 94, 2401-2411. [CrossRef]

49. Bavadekar, S.; Panchal, P.; Hanbashi, A.; Vansal, S. Cytotoxic effects of selective serotonin- and serotonin-norepinephrine reuptake inhibitors on human metastatic breast cancer cell line, MCF-7 (842.3). FASEB J. 2014, 28, 842. [CrossRef]

50. Minguez, L.; Halm-Lemeille, M.-P.; Costil, K.; Bureau, R.; Lebel, J.-M.; Serpentini, A. Assement of cytotoxicity and immunomodulatory properties of four antidepressants on primary cultures of abalone hemocytes (Haliotis tuberculate). Aquat. Toxicol. 2014, 153, 3-11. [CrossRef]

51. Ilgin, S.; Dagasan, F.; Donmez, D.B.; Baysal, M.; Ekliglu, O.A. Evaluation of the hepatotoxic potential of citalopram in rats. J. Fac. Pharm. Istanb. Univ. 2019, 50, 188-194.

52. Ahmadian, E.; Eftekhari, A.; Fard, J.K.; Babaei, H.; Nayebi, A.M.; Mohammadnejad, D.; Eghbal, M.A. In vitro and in vivo evaluation of the mechanisms of citalopram-induced hepatotoxicity. Arch. Pharm. Res. 2017, 40, 1296-1313. [CrossRef]

53. Jimenez-Holgado, C.; Sakkas, V.; Richard, C. Phototransformation of three psychoactive drugs in presence of sedimental water extractable organic matter. Molecules 2021, 26, 2466. [CrossRef]

54. Jakimska, A.; Śliwka-Kaszyńska, M.; Nagórski, P.; Kot-Wasik, A.; Namieśnik, J. Environmental Fate of two psychiatric drugs, dizaepam and sertraline: Phototransformation and investigation of their photoproducts in natural waters. J. Chromatogr. Sep. Tech. 2014, 5, 253.

55. Shen, L.Q.; Beach, E.S.; Xiang, Y.; Tshudy, D.J.; Khanina, N.; Horwitz, C.P.; Bier, M.E.; Collins, T.J. Rapid, biomimetic degradation in water of the persistent drug sertraline by TAML Catalysts and hydrogen peroxide. Environ. Sci. Technol. 2011, 45, 7882-7887. [CrossRef] [PubMed]

56. Beretsou, V.G.; Psoma, A.K.; Gago-Ferrero, P.; Aalizadeh, R.; Fenner, K.; Thomaidis, N.S. Identification of biotransformation products of citalopram formed in activated sludge. Water Res. 2016, 103, 205-214. [CrossRef] [PubMed] 